\title{
Effect of Salicylic Acid Pretreatment on Germination of Wheat under Drought Stress
}

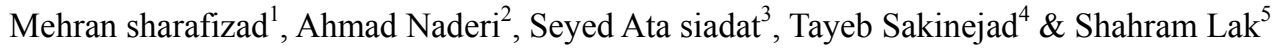 \\ 1 PhD. Student, Department of Agronomy, Science and Research Branch, Islamic Azad University, \\ Khouzestan-Iran \\ ${ }^{2}$ Academic staff, Khuzestan Research Center \\ ${ }^{3}$ Professor, Department of Agronomy and Plant Breeding, Dezful Branch, Islamic Azad University Khouzestan, \\ Iran \\ ${ }^{4}$ Department of Agronomy and Plant Breeding, Science and Research Branch, Islamic Azad University, Ahwaz, \\ Iran \\ ${ }^{5}$ Associated professor, Department of Agronomy and Plant Breeding, Science and Research Branch, Islamic Azad \\ University, khouzestan, Iran \\ Correspondence: Mehran sharafizad, Department of Agronomy, Science and Research Branch, Islamic Azad \\ University, Khouzestan-Iran. E-mail: msharafizadeh@yahoo.com
}

Received: November 29, 2012 Accepted: December 19, 2013 Online Published: February 17, 2013

doi:10.5539/jas.v5n3p179

URL: http://dx.doi.org/10.5539/jas.v5n3p179

\begin{abstract}
Seed priming increases enzyme of antioxidants such as glutathione and ascorbate in seed. These enzymes decrease the activities of lipid peroxidation in stage of germination. As a result, increases the percentage of germination. The aim of this survey is to study the effect of the pretreatment of salicylic acid under the condition of drought stress on features of germination. This research is performed in December 2011, in laboratory of seed control branch of Khuzestan. Wheat seeds of Chamran cultivars were transferred to Petridish containing $10 \mathrm{ml}$ solution of polyethylene Glycol (6000) with potential [0 ( control), $-5,-10$ and -15 bar] after soaking in solution [0 (distilled water, $0.7,1.2,2.7 \mathrm{mM}]$ of salicylic acid for 24 hours for germination under the condition of drought stress. The result showed that the greatest impact of salicylic acid on reducing the germination time was at low level of stress. The highest percentage of germination and affecting traits on it was obtained byseed soaking treatment with salicylic acid with minimum amount $(0.7 \mathrm{mM})$. the best result was obtained from low level of stress. The percentage of germination had positive and significant correlation with : average daily germination $\left(0.988^{* *}\right)$, coefficientof germination rate $\left(0.971^{* *}\right)$, length of radicle $\left(0.363^{* *}\right)$, length of plumule $\left(0.604^{* *}\right)$ length of seedling $(0.765 * *)$ and seed vigor $\left(0.870^{* *}\right)$ and it has negative and significant correlation with: daily germination rate $\left(-0.935^{* *}\right)$, germination energy $\left(-0.7668^{* *}\right)$ and Allometric trait $\left(-0.501^{* *}\right)$. More energy is required for germination in high density of SA and high level of drought stress, in addition, the time needed for germination will be more. Seed vigor and power index off seedling decreased in high density of SA and high level of drought stress.
\end{abstract}

Keywords: salicylic acid, germination, wheat, drought stress

\section{Introduction}

\subsection{Effect of Plants Growth Regulators in Prevent Destructive Effect of Conditions Stress}

In drought condition, using some plant growth regulators such as salicylic acid and cycocel might be an effective strategy to prevent destructive effect of drought and provide plant compatibility. The use of these regulators increases plant tolerances to abiotic and biotic stresses. These regulators are known as a strategy to prevent the harmful effect of environmental stresses. These stresses include: heat, cold, heavy metals and drought.

\subsection{The Role Salicylic Acid in the Regulation of Plant Physiological Processes}

Salicylic acid is a natural phenolic compound of endogenous regulators among the group of Ortho hydroxy benzoic acid. Salicylic acid (SA) has an important role in the regulation of important physiological processes such as growth of plants, plant evolution, creating flowers, cell division, control of ion uptake by roots and 
photosynthesis, apertureclosure through neutralizing free radicles or reactive oxygen (Gomez et a1., 1993). Salicylic acid also enhances salt tolerance in wheat seedlings (Shakirova et al., 1997) and resistance to water shortages. In a study, the use of salicylic acid in soybean plants had significant effect, on seedling growth and root dry weight. The best result was obtained by soaking seed treatment with salicylic acid with a minimum amount (0.1 / MM), (Cakmad et al., 1991). In a study it was reported that seed priming increases antioxidant enzymes such as glutathione in the seeds. These enzymes reduce Lipid peroxidation activity in germination stage,so increasesthe percentage of germination Increasing stress levels reduces the percentage of germination. This decrement salinity stress (toward drought stress) is disturbed due to Osmotic pressure, water absorption process and then alpha amylase enzyme activity is intercepted (Zhou, 2009). In one experiment it was found that germination rate of the seeds Prime (mulberry Fox plant) with salicylic acid under drought and salinity stress was greater than control treatment, but decreased by increasing the level of drought and salinity stress (Zares \& Tavili, 2000). Application of salicylic acid in plant mulberry fox reduces germination time and the greatest impact on reducing the duration of germination was at low levels of stress (Zares \& Tavili, 2000). Salicylic acid reduces the duration of watermelon seeds germination. It causes that the germination of primed seeds begins earlier than the control, therefore in stress conditions, these seeds come out of the soil earlier and the establishment is faster and be exposed less time to pests and diseases to be splashing (Hus \& Sung, 1997). In a research, Wheat and barley seed priming with salicylic acid enhances the antioxidant activity and increased seedlingstresstolerance (Hanan, 1992). The salt tolerance increased in wheat seedlings when seeds were pretreated with salicylic acid (Hamada \& Al- Hakimi, 2001). Soybean seeds soaking in salicylic acid $(0.6 \mathrm{mM})$ for 6 hours caused a positive effect on the accumulation of some ions and antagonists, or modifying the inhibitory effect of drought stress (Al- Hakimi, 2006). It was reported that Reducing the biomass of wheat seedlings caused by stress, was compensated by the use of polyethylene glycol (PEG) to some extent by seed treatment with SA (Agarwal et al., 2005).

\subsection{Hypotheses and Aim of this Study}

In this study the effect of salicylic acid pretreatment on the components of germination under stress conditions was studied.

\section{Method}

\subsection{Location and Experimental Design}

This research was performed infall 2010-2011 in the laboratory of seed control branch located in the center of agricultural research Safiabad Dezful, Khuzestan.The center, located $120 \mathrm{~km}$ north of Ahwaz with 82 meters height above sea level and latitude 32 degrees 22 minutes North and longitude 48 degrees 32 minutes east. It is located in South West of Iran. Generally, the southern coasts of all the lands that their height is less than 100 meters, has a desert climate. So the climate of Khuzestan province is arid and semiarid. Wheat cultivar that is studied is Chamran. This cultivar has the greatest cultivation of wheat in Khuzestan (about 70\% of Khuzestancultivation).

\subsection{Treatment Preparation}

This study is performed in a randomized factorial method with 4 replications. Method of testing was so that the 25 seeds from each treatment are separated and after sterilization with Benomyl fungicides for two minutesand drying them under room temperature $\left(25^{\circ} \mathrm{C}\right)$,seeds were soaked insolutions with concentrations of 0 (distilled water), 0.7 , 1.2 and 2.7 salicylic acid for 24 hours separately,then,the Soaked seed papers were transferred to Petri dishes containing Whatman No.1 and To apply drought stress, polyethylene glycol (6000)(with potential (0 (distilled water), $-5,-10,-15$ bar) to $10 \mathrm{ml}$ per Petri dish was used. The Lids of Petri dishes were closed completely with paraffin and located in germinator under light conditions (light) at $25^{\circ} \mathrm{C}$ for 16 hour and under darkness (night) at a temperature of $15^{\circ} \mathrm{C}$ and about $60 \%$ humidity for 8 hour for germination. Since the second day of experiment, the number of germinated seeds was counted every day (Standard germination is when the root tip was approximately $2 \mathrm{~mm})$.

\subsection{Treat Estimated and Formula}

After the final day of testing (the 7th day), mean daily germination, percentage of germination, mean germinationtime, germinationrate, germinationenergy, allometric trait, seedling strength index was calculated using the following formulas:

\subsubsection{Mean Time of Germination (MTG)}

MTG is indicator of the acceleration is calculated from the following equation (Ellis \& Roberts, 1981): 


$$
M T G=\frac{\Sigma(n d)}{\Sigma n}
$$

$\mathrm{n}$ : The number of germinations during $\mathrm{d}$ days.

$\mathrm{d}$ : The number of days, since the beginning of germination.

$\sum \mathrm{n}=$ Total number of germinated seeds.

2.3.2 Mean Daily Germination (MDG)

MDG is an indicator of dailygermination rate calculated from the following equation (Scott \& Willams, 1984)

$$
\mathrm{MDG}=\frac{\mathrm{FGP}}{\mathrm{d}}
$$

\subsubsection{Final Germination Percentage (FGP)}

$\mathrm{d}$ : The number of days to reach maximum final germination(the experiment period).

\subsubsection{Daily Germination Speed (DGS)}

This index is inverse of mean daily germination (Huntr \& Naylov, 1984):

$$
\mathrm{DGS}=\frac{1}{\mathrm{MDG}}
$$

\subsubsection{Coefficient of Velocity of Germination (CVG)}

This index is characterized by speed and acceleration of germination and calculated from the following equation (Maguire, 1962).

$$
C V G=\frac{G_{1}+G_{2}+G_{3}+\ldots+G_{n}}{\left(1 \times G_{1}\right)+\left(2 \times G_{2}\right)+\left(3 \times G_{3}\right)+\ldots+\left(n \times G_{n}\right)}
$$

G1-Gn: the number of germinations since the first day until the last day.

\subsubsection{Percentage of Germination:}

We use the following formula to calculate the percentage of germination (Nicols, 1968).

$$
\{\mathrm{S} / \mathrm{T}\} * 100
$$

S: The number of germinated seeds.

$\mathrm{T}$ : Total number of seeds.

\subsubsection{Vigor Index of Seed}

The Length of Seedling * the Number of Germinated Seeds in the Last Day of Counting (Agraval, 2003).

\subsubsection{Germination Energy}

The number of germinated seeds in the first day of counting / 100 (Nicols, 1968).

\subsubsection{Allometric Trait}

The length of radicle / the length of plumule (Nicols, 1968).

\subsubsection{Power Index of Seedling}

After determining the normal and abnormal seedlings,10seedlings were randomly selected and then, length of seedling and primary leaves and primary roots were determined Seedling power index was calculated by using the following equation (Abdul-Baki \& Anderson, 1973). 
PINS = final percentage of germination* \{average primary root length+average primary shoot length

The radicle length, plumule length and seedling length were measured, to evaluate aforesaid evaluations, 5 seedlings were randomly selected and their length was determined by the ruler.

\section{Results and Discussion}

\subsection{Statistics and Data Analysis}

Analysis of variance and mean comparison of this experiment shows that using salicylic acid could increase plant tolerance to drought stress but it is significantly related to the time and dosage of application of salicylic acid.

\subsection{Percentage of Germination}

According to the results listed in (Table 1) it can be seen that there is significant differences between the different levels of priming and salicylic acid (SA) and various potential drought stress levels caused by polyethylene glycol (PEG) and the treatment interaction effects at the $1 \%$ probabilitylevel. After the control treatment (priming with distilled water), the highest percentage of germination was forlow concentrations of SA $(0.7 \mathrm{mM})$ andgermination percentage decreased with increasing concentrations of SA (Figure 1). By considering simple effects of drought stress levels, it can be seen that the highest percentage of germination is related to low levels of drought stress $(-5$ bar), then, control treatment, and byincreasing the level of stress duetoosmotic potential of PEG, germination rate is reduced (Figure 2). The highest percentage of germination was associated with a3b1treatment and the lowest percentage of germination was for $\mathrm{a} 4 \mathrm{~b} 3$ treatment (Figure 3) as a result, the highest percentage of germination, it has been observed in middle concentration of SA $(1.2 \mathrm{mM})$ and low level of drought stress. The lowest percentage of germination isoccurred athighconcentrations of SA $(2.7 \mathrm{mM})$ with an intermediate level of stress. Pretreatment with SA causes the seeds to be less affected by drought effects due to increased seed germination and seedling growth.

Table 1 . Analysis of variance (mean squares) traits estimated in laboratory

\begin{tabular}{|c|c|c|c|c|c|c|c|c|c|c|c|c|c|}
\hline S. O. V & Df & $\begin{array}{l}\text { Percentageof } \\
\text { germination }\end{array}$ & $\begin{array}{l}\text { Length of } \\
\text { radicle }\end{array}$ & $\begin{array}{l}\text { Lengthof } \\
\text { plumule }\end{array}$ & $\begin{array}{l}\text { Lengthof } \\
\text { seedling }\end{array}$ & MDG & MTG & DGS & $\mathrm{CVG}$ & EG & Allometric & $\begin{array}{c}\text { Seedling } \\
\text { strength } \\
\text { index }\end{array}$ & $\begin{array}{l}\text { Seed } \\
\text { vigor }\end{array}$ \\
\hline Piming withSA(A) & 3 & $1719 / 563 * *$ &.$/ 018^{*}$ & $\mathbf{0} / 005^{*}$ &.$/ 040 * *$ & $47 / 231 * *$ & 1871/733ns &.$/ 008 * * 3$ & $3983 / 710 * *$ & $1 / 759 * *$ & $* \quad . / 041 \mathrm{~ns}$ & $2 / 829 * *$ & $1 / 923 * *$ \\
\hline Strees with PEG(B) & 3 & $5868 / 854 * *$ &.$/ 018^{*}$ &.$/ 044 * *$ &.$/ 188 * *$ & $183 / 994 * *$ & *1214/360ns & $: / 024 * * 7$ & $7712 / 874 * *$ & *1/377** & $* . / 413 * *$ & $4 / 243 * *$ & $6 / 136^{* *}$ \\
\hline $\begin{array}{c}\text { Drought } \\
\text { strees*prime }\left(\mathrm{A}^{*} \mathrm{~B}\right)\end{array}$ & 9 & $440 / 854 * *$ &.$/ 008 \mathrm{~ns}$ &.$/ 007 * *$ &.$/ 016^{*}$ & $12 / 170 *$ & $1668 / 752 \mathrm{~ns}$ &.$/ 002 *$ & $723 / 744 * *$ &.$/ 221 * *$ &.$/ 017 \mathrm{~ns}$ &.$/ 535 * *$ &.$/ 392 * *$ \\
\hline Trail error & 48 & $154 / 031$ &.$/ 005$ &.$/ 001$ &.$/ 006$ & $4 / 436$ & $1192 / 383$ &.$/ 001$ & $255 / 493$ &.$/ 056$ &.$/ 033$ &.$/ 112$ &.$/ 081$ \\
\hline C.V\% & & $9 / 20$ & $2 / 88$ & $1 / 51$ & $1 / 16$ & $9 / 45$ & $4 / 74$ & $23 / 41$ & $24 / 74$ & $7 / 14$ & $6 / 80$ & $6 / 52$ & $7 / 69$ \\
\hline
\end{tabular}

ns: non significant, ${ }^{*},{ }^{* *}$ : respectively significant $(\mathrm{p} \leq 0.05)$ and highly significant $(\mathrm{p} \leq 0.01)$.

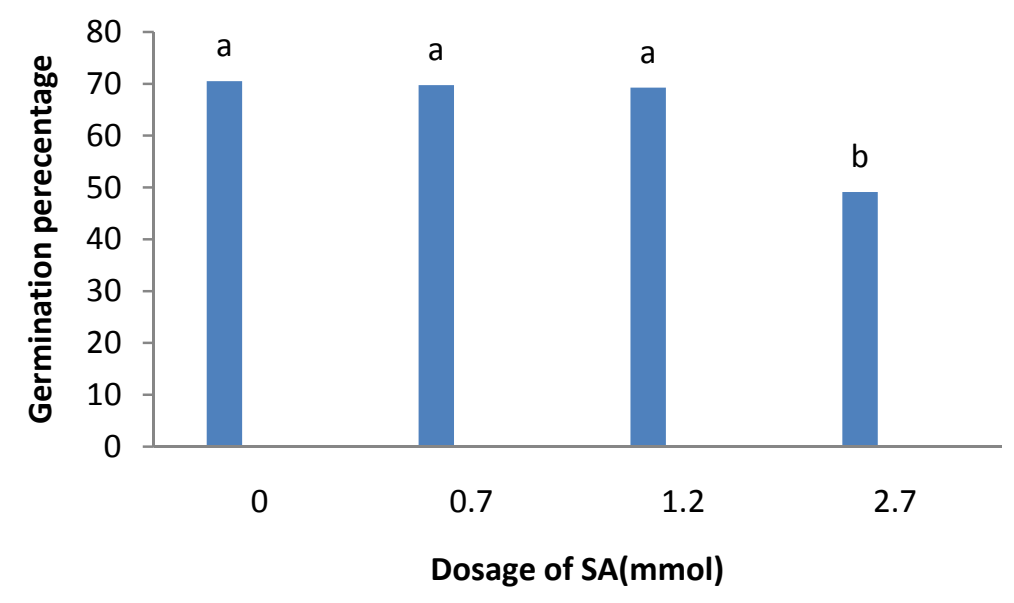

Figure 1. Effect of SA dosage on germination percentage 


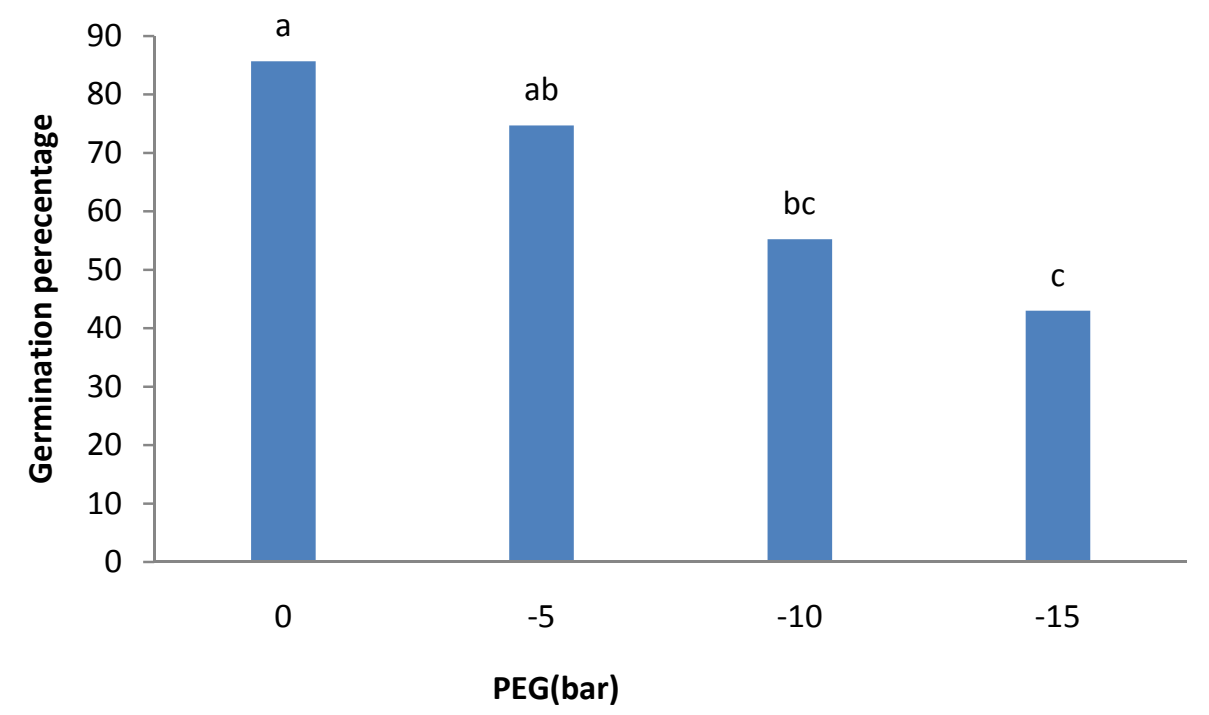

Figure 2. Effect of drought stress (PEG) on germination percentage

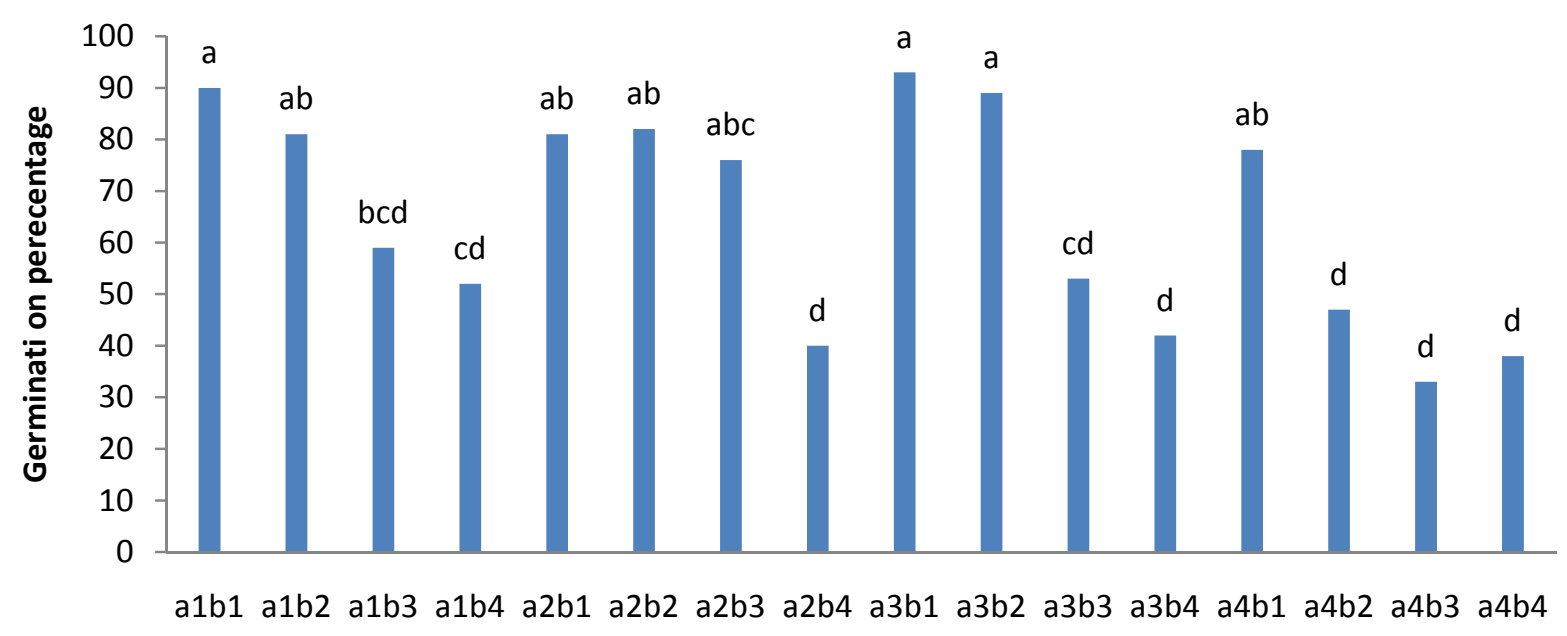

Priming and drought stress

Figure 3. Effect of drought stress(PEG) and priming(SA)on germination percentage

\subsection{Length of Radicle}

As can be seen in Table 1, analysis of variance in terms of the length of radicle, shows that there is significant differences between different levels of priming and drought stress, at the level of 5\%. By comparing the means it can be seen that the highest average length of radicle is related to a low dose of SA with $(2.56 \mathrm{~cm})$ and the lowest length $(2.48 \mathrm{~cm}$ ) was associated with high dose of SA (Figure 4). In a study, priming of wheat seeds with $0.5 \mathrm{mM}$ SA increased cell division of priming of wheat seeds with $0.5 \mathrm{mM} \mathrm{SA}$ increased cell division of meristem of wheat radicle, which is consistent with the results of this study. (Hamada \& Al-Hakimi, 2001).

By observing (Figure 5) you can see that the maximum length of radicle is related to the osmotic potential (-10 bar) and the shortest length is related to the osmotic potential of (-15 bar).The result is that increasing the stress level up to about -10 bar, the length of radicle increases but with increasing more than -10 bar, not only no increasing in the length of the radicle was occurred, but also it decreased. By considering the interaction effects between treatments, 
we observed that maximum radicle length was associated with a $2 \mathrm{~b} 3$ treatment and the minimum length was associated with a3b4 treatment (Figure 6). It was explained that low level of SA and osmotic potential -10 bar had maximum radicle length.

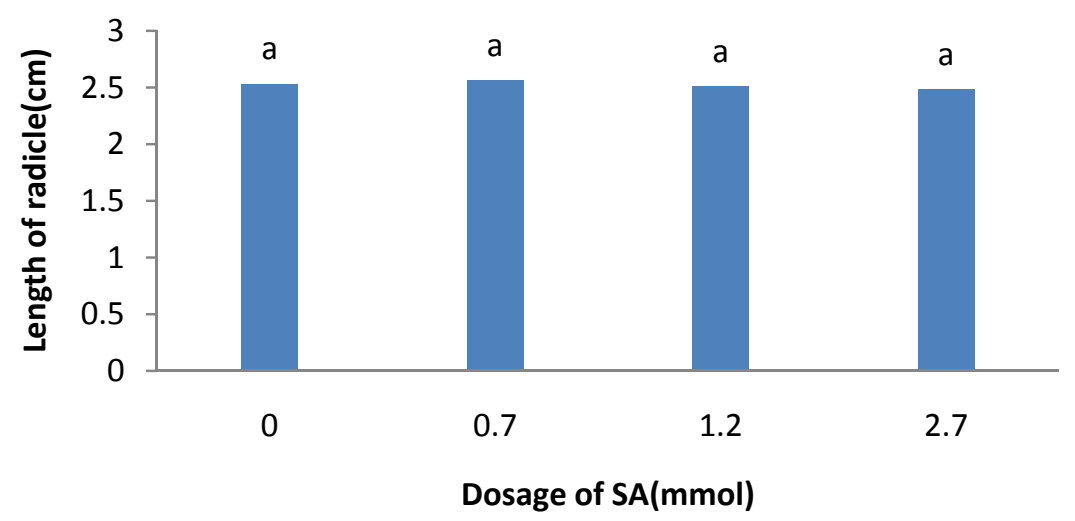

Figure 4. Effect of SA dosage on length of radicle

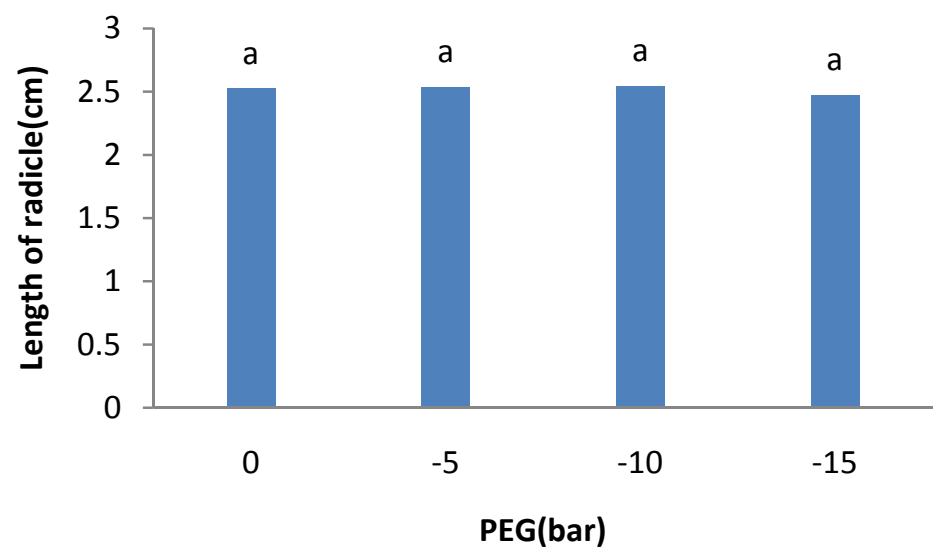

Figure 5. Effect of drought stress (PEG) on length of radicle

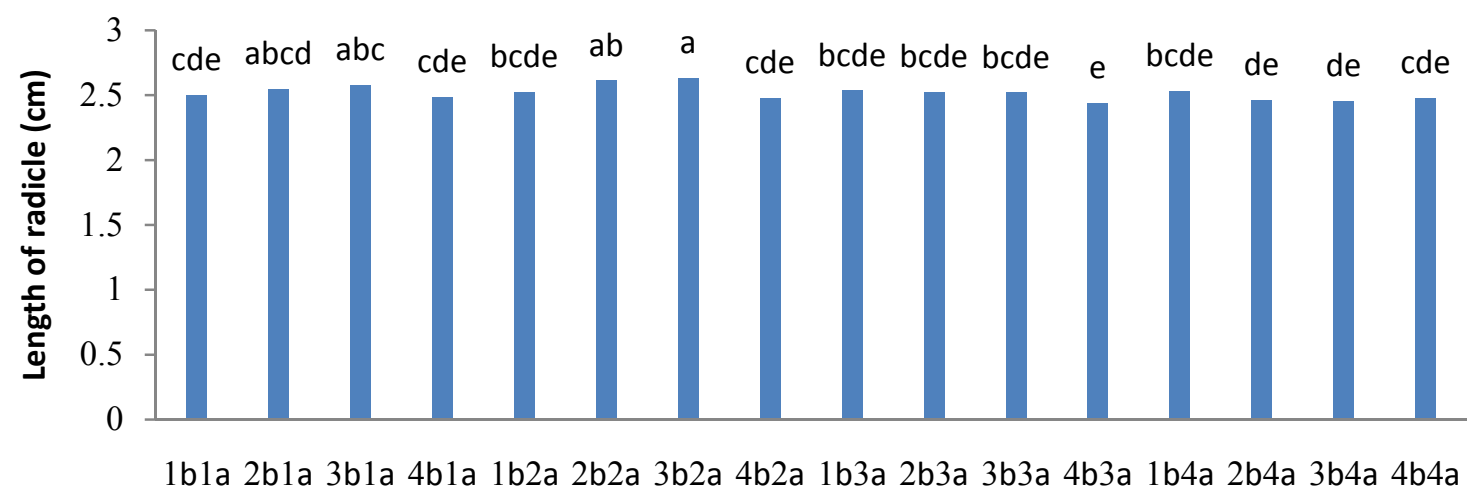

Priming and drought stress

Figure 6. Effect of drought stress (PEG) and priming (SA) on length of radicle 


\subsection{Length of Plumule}

As can be seen in Table 1, analysis of variance showed that in terms of the length of plumule,there is significant differences between different levels of priming and SA at the level of $5 \%$.and there is significant difference between drought stress and treatment interaction for this trait at the level of $1 \%$. By comparing the means of different level of priming Figure 7 we observed that low doses of SA $(0.7 \mathrm{mM})$ hasthe highest plumule length $2.395 \mathrm{~cm}$ and the minimum plumule length was associated with high doses of SA $(0.7 \mathrm{mM})$. The result of this review is that due to seed priming with salicylic acid, plumule length decreased by increasing the concentration of this hormone. By reviewing the diagram of drought (Figure 8). It can be seen that the maximum length of plumule is observed after control treatment related to low potential of drought stress, and by increasing the level of stress, the length of this feature is decreased. Figure 9 shows that the maximum length of stipes is related to interaction of a $3 \mathrm{~b} 1$ treatment,it means middle dose of SA with control treatment (without stress). And the minimum length of stipes trait is related to the a $3 \mathrm{~b} 3$ treatment. This shows that the low and medium concentration SA have a positive impact on this trait, these concentrations can have influence on this trait at low levels of stress and in high level of stress, SA can not adjust the effects of drought stress on this trait.

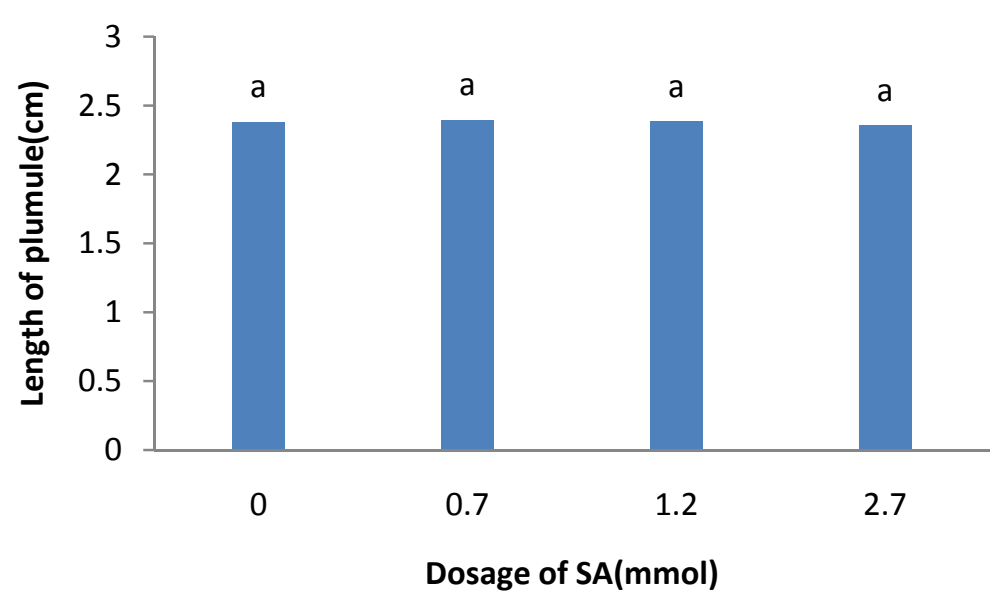

Figure 7. Effect of SA dosage on length of plumule

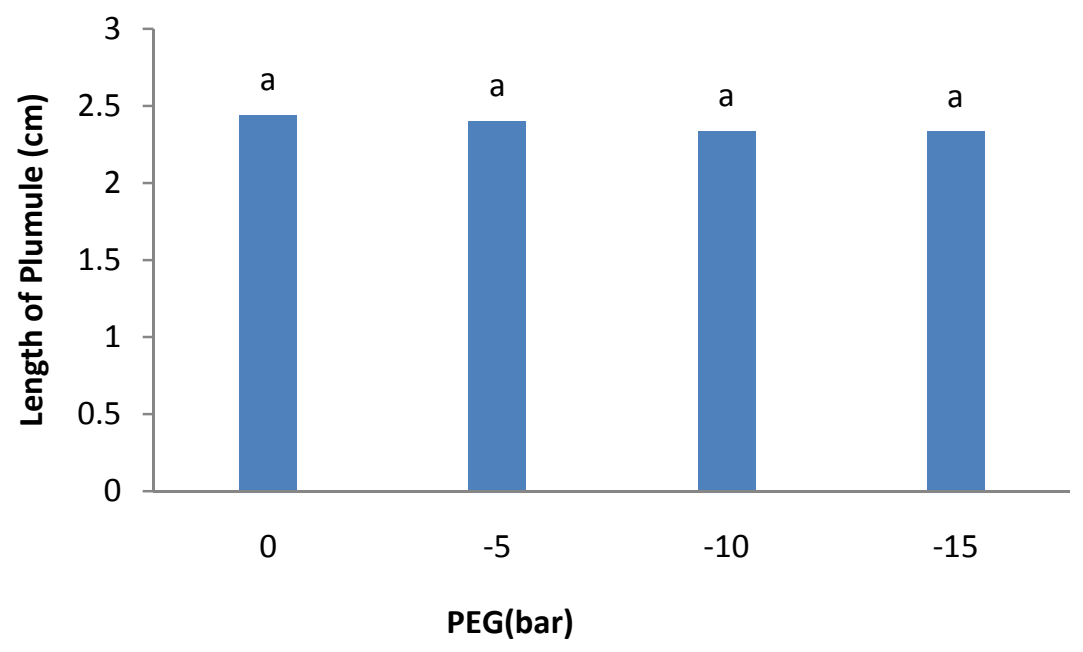

Figure 8. Effect of drought stress (PEG) on length of plumule 


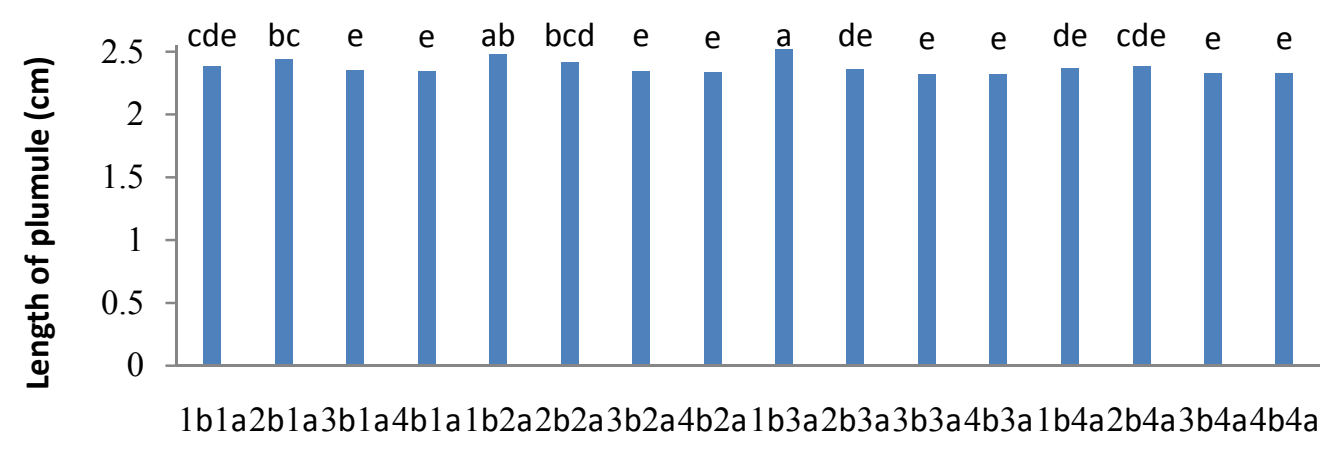

Priming and drought stress

Figure 9. Effect of drought stress (PEG) and priming (SA)on length of plumule

\subsection{Length of Seedling}

The results of the Analysis of variance of seedling length in Table 1 shows that there is significant differences between different levels of priming and SA and there is significant differences between different level of drought stress due to PEG at the level of $1 \%$, there is also significant difference between treatment interactions at the level of 5\%. By Duncan's test comparing the means it was observed that despite all the levels of Prime are located with SA in a group (Figure 10), but The the greatest attribute of seedling length is related to low concentration of SA is and with increasing concentrations of this hormone, this trait is also reduced so that the minimum of seedling length is related to high dosage of this hormone $(2.7 \mathrm{mM})$. In one research, the use of salicylic acid on soybean plants had significant effects on seedling growth and root dry weight. The best result obtained by soaking seed treatment in salicylic acid with a minimum amount $(0.7 \mathrm{mM})$ (Al-Hakimi, 2006). According to positive and significant correlation between these traits and radicle length and plumule length (Table 2). As expected, the low concentration of SA had maximum length of radicle and plumule, therefore it has maximum length of seedling. Comparing the means between different level of drought stress. Figure 11 shows that maximum length of seedling is for control treatment (without stress) and the minimum length is related to high level of stress (-15 bar), increasing stress, decreases this trait. By reviewing the diagram of interactions between treatments (Figure 12) it can be seen that the greatest seedling length is for $\mathrm{a} 3 \mathrm{~b} 1$ treatment and the minimum length of seedling length is for a4b4 treatment. As mentioned before, low and middle level of SA has maximum seedling length and treatment without drought stress has maximum seedling length.

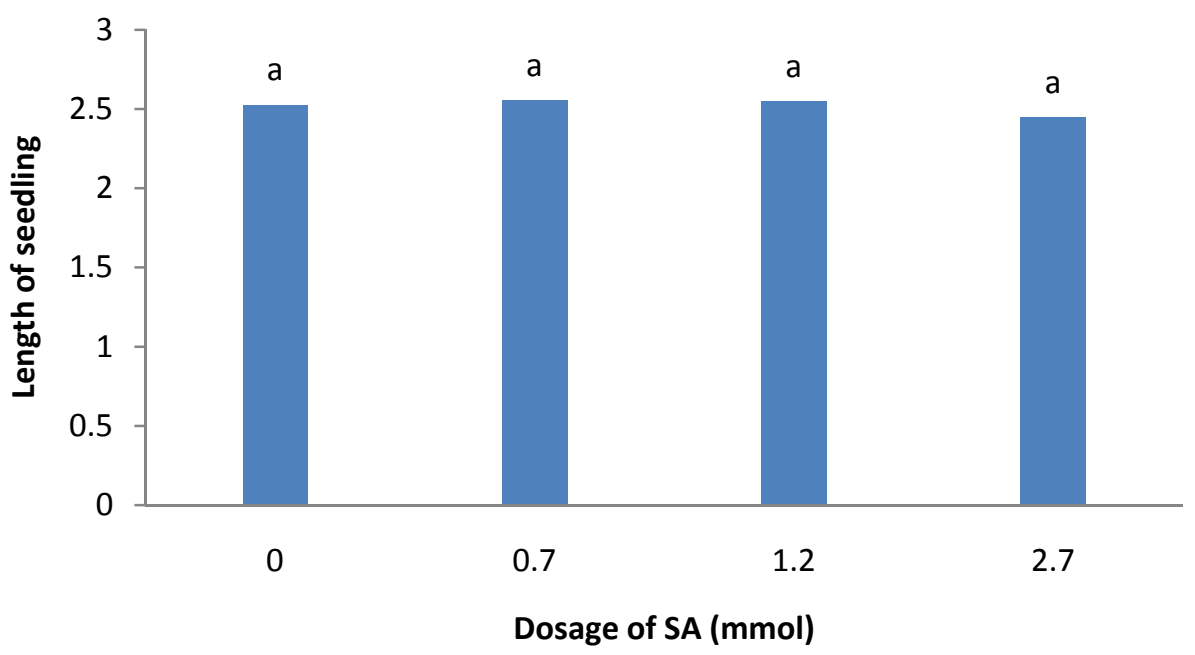

Figure 10. Effect of SA dosage on length of seedling 


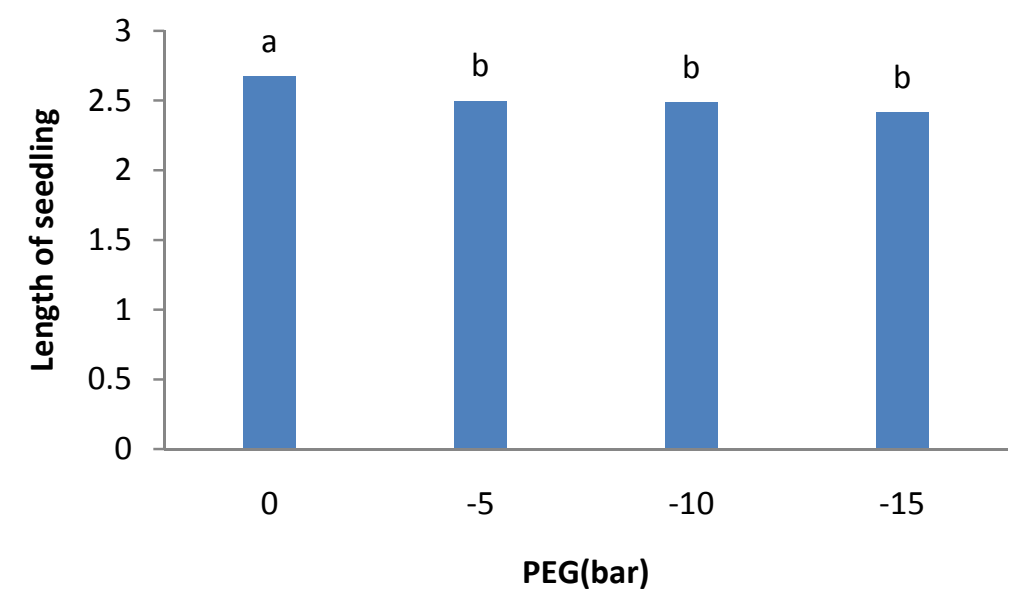

Figure 11. Effect of drought stress(PEG) on lengthof seedling

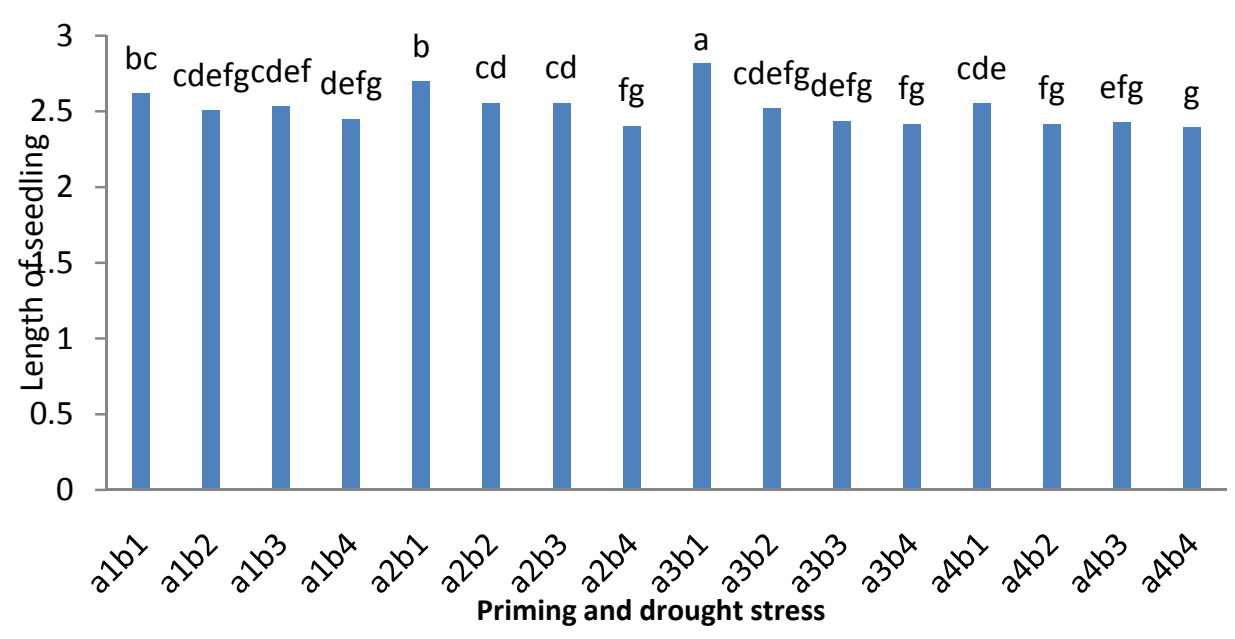

Figure 12. Effect of drought stress(PEG) and priming(SA)on length of seedling

\subsection{Mean Daily Germination (MDG)}

This trait is an index of the velocity and acceleration of germination and speed of germination. Analysis of variance in (Table 1) shows that there is significant differences between the different levels of priming and drought stress at the level of $1 \%$ and there is significant differences between treatment interaction effects at the $5 \%$ level. Comparison between the average levels of seed priming with SA shows that the highest mean daily germination after control treatment is occurred with low dose of SA $(0.7 \mathrm{mM})$. By increasing the concentration of SA, this trait is decreased (Figure 13), this is the result of the high and positive correlation $\left(0.988^{* *}\right)$ between MDG and the percentage of germination (Table 12). Control treatment (without stress) had maximum mean daily germination (Figure 14), increasing the level of drought stress, decreases this trait. Considering interaction effects (Figure 15) also shows that the highest mean daily germination traits is 15.15 associated with alb1 treatment and minimum is associated with a4b4 treatment. 


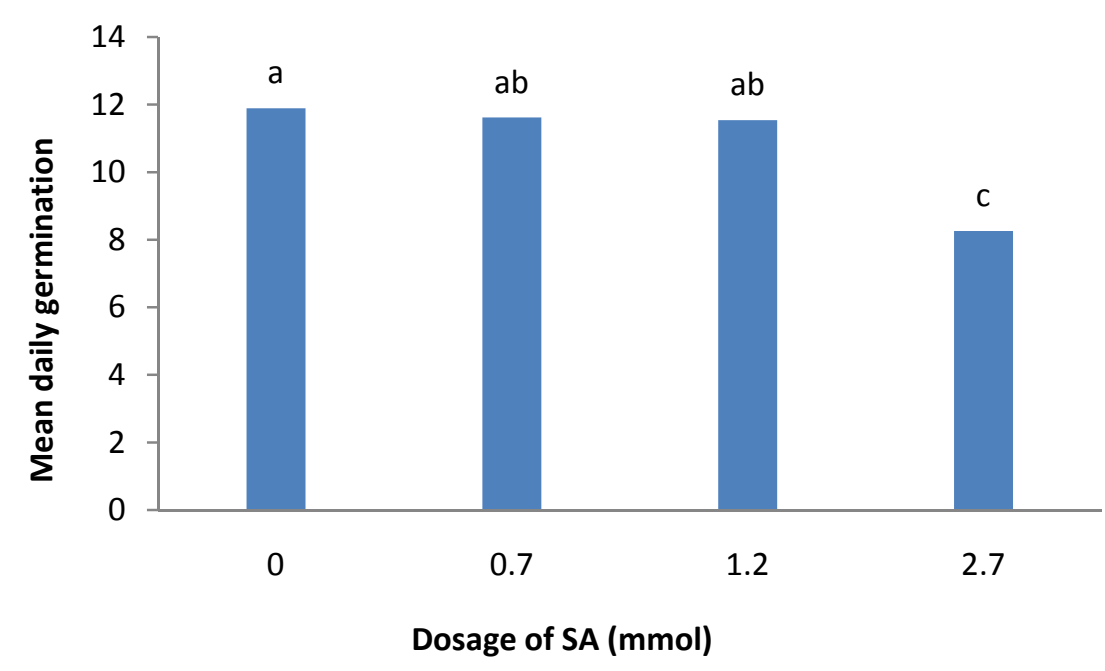

Figure 13. Effect of SA dosage on mean daily germination

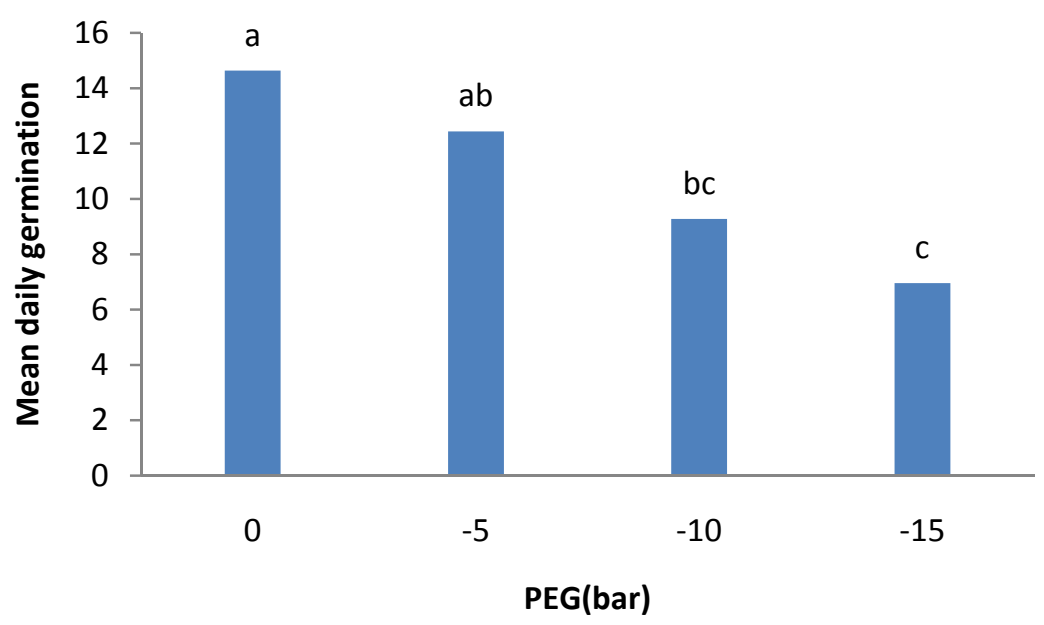

Figure 14. Effect of drought stress(PEG) on mean daily germination

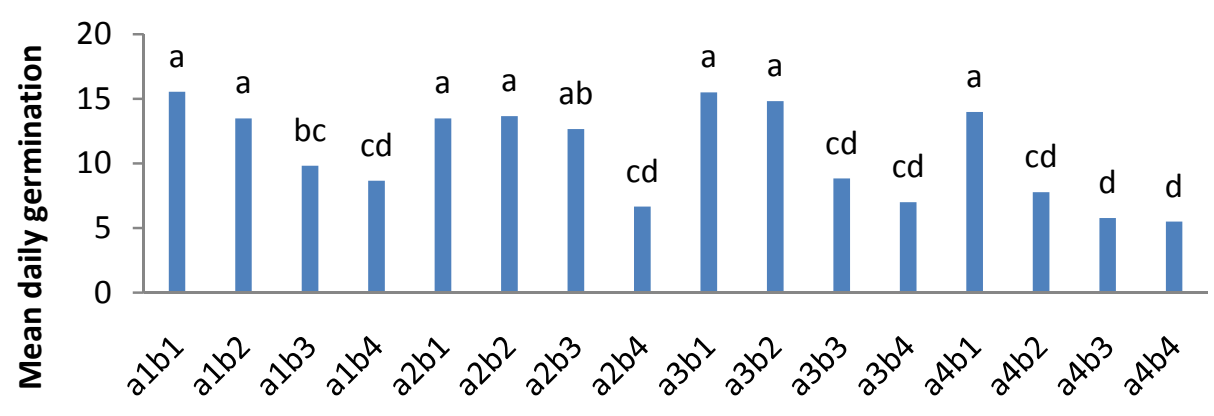

Priming and drought stress

Figure 15. Effect of drought stress(PEG) and priming(SA)on mean daily germination 


\subsection{Mean Time for Germination (MTG)}

This trait is an index of the velocity and acceleration of germination and speed of germination. Table 1 analysis of variance shows that there is no significance difference in this trait between the treatments. Comparison between the average levels of seed priming (Figure 16) shows that by increasing the concentration of SA, mean time for germination is increased. In a research,the application of salicylic acid in fox berries was studied, the greatest impact of salicylic acid on the germination time was obtained at low levels of stress that is consistent with the results of this study. Salicylic acid reduces seed germination time, and causes that germination of primed seeds starts earlier than in control, as a result, in stress condition, these seeds get out of the soil earlier and established faster And less time exposed to pests and diseases to be splashing (Agarwal et al., 2005). By comparing the level of drought stress (Figure 17) we can see that by increasing the level of stress, mean time for germination is increased. generally, seed priming with low concentration of SA causes increasing the percentage of germination. Increasing in the level of drought stress also causes decreasing the percentage of germination and delay in germination beginning. Figure 18 shows the average interaction between treatments so that the highest mean time for germination is associated with a $4 \mathrm{~b} 2$ treatment and the lowest mean time for germination was associated with a $4 \mathrm{~b} 4$. As mentioned before, by increasing the concentration of SA and the level of drought stress, time required for germination is decreased.

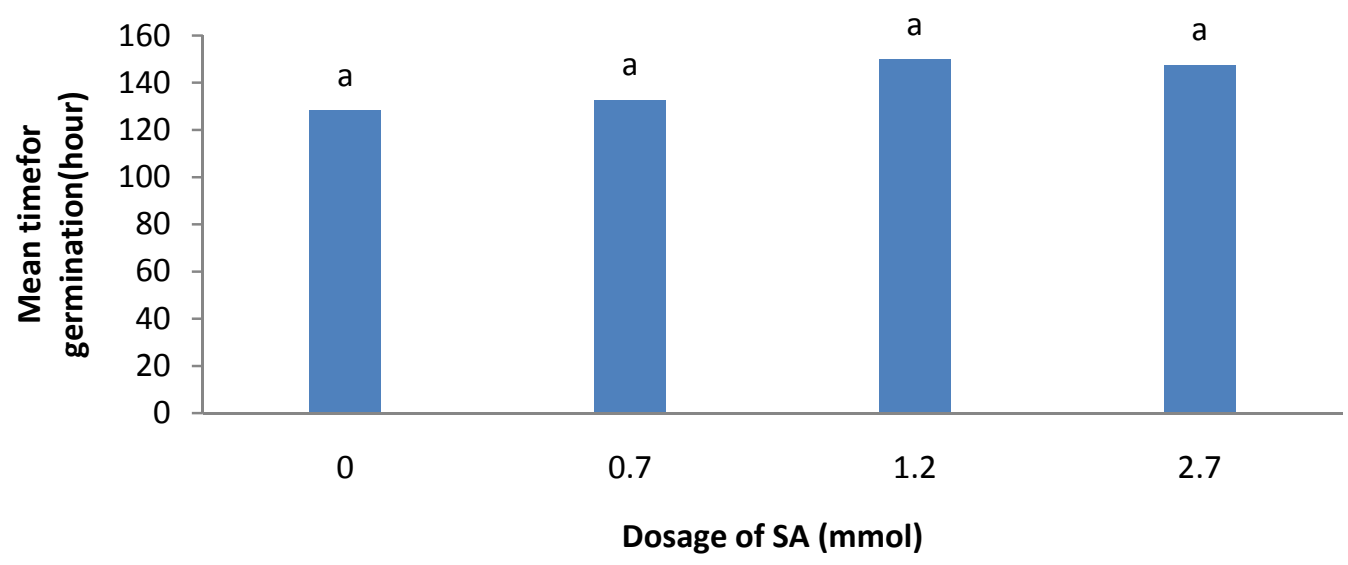

Figure 16. Effect of SA dosage on mean timefor germination

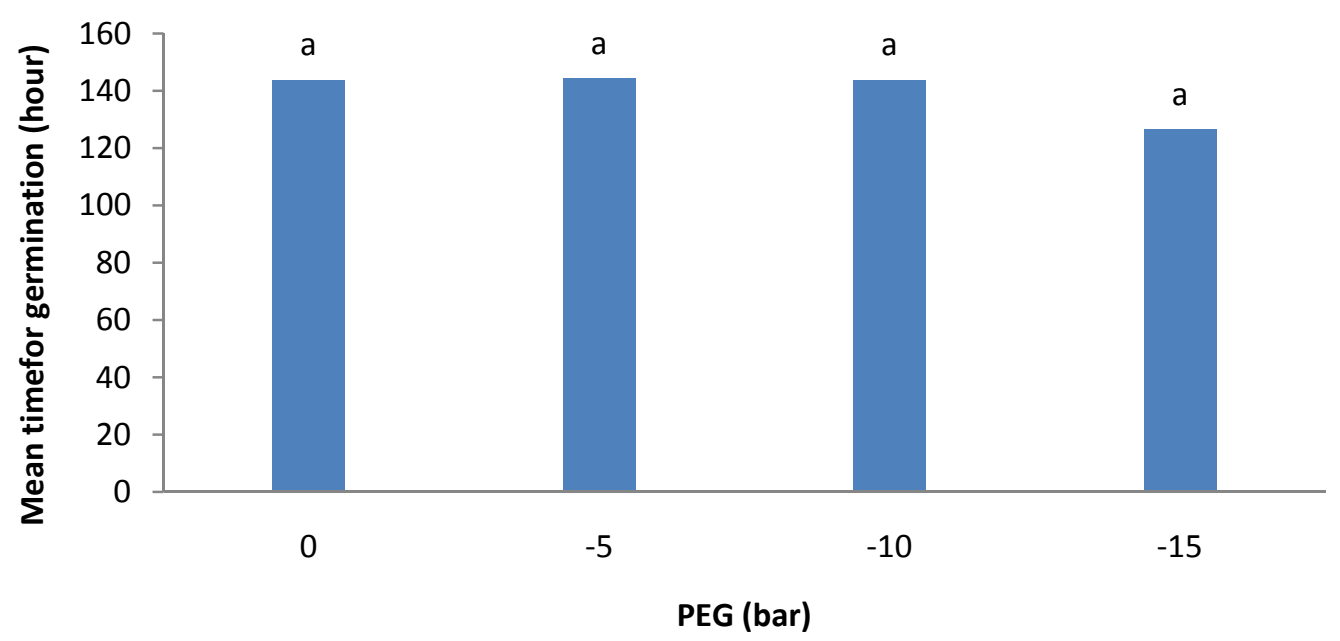

Figure 17. Effect of drought stress (PEG) on mean time for germination 


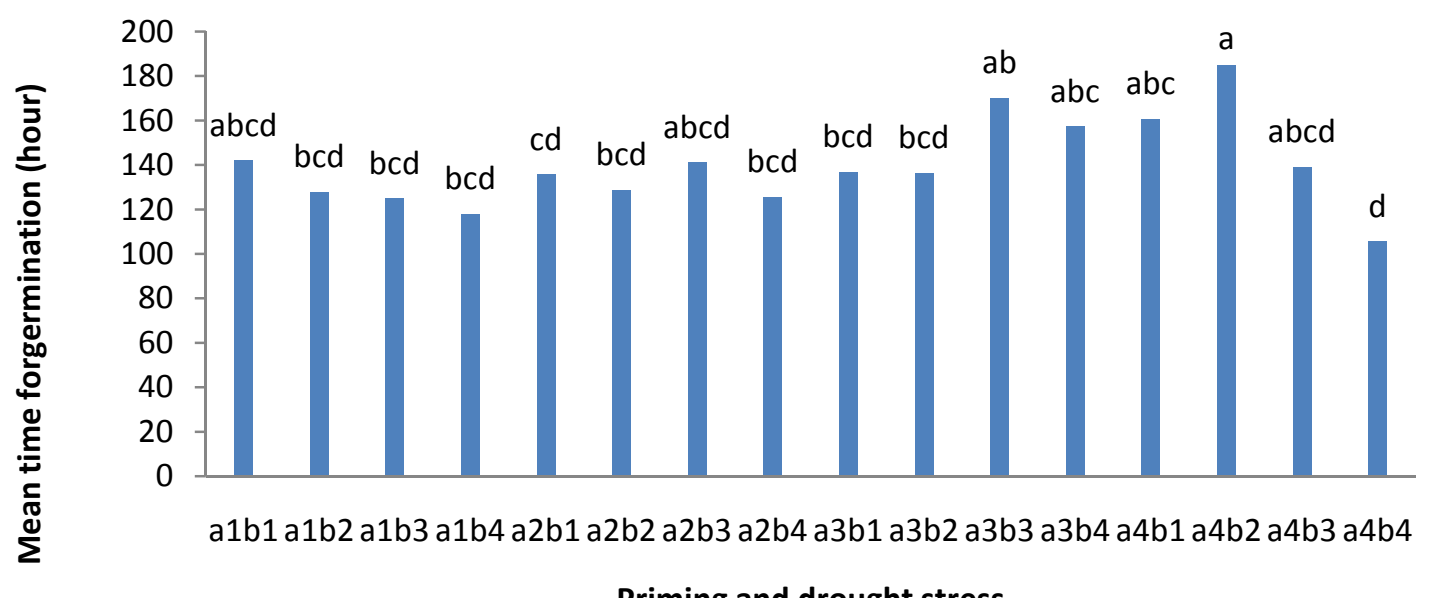

Figure 18. Effect of drought stress (PEG) and priming (SA) on mean time for germination

\subsection{Daily Germination Speed (DGS)}

We can see in analysis of variance Table (Table1) that, there is significant differences between daily germination speed in different treatments of seed priming with SA and different level of drought stress with PEG in the level of $1 \%$ and interaction between these two treatments in the level of 5\%. By comparing means of different levels of seed priming with SA (Figure 19) we can be see that the highest daily germination speed is associated with high dose of SA (2.7 mM ). By comparing Means of different levels of drought stress (Figure 20) it is also observed that the highest daily germination speed is associated with high levels of droughtstress ( -15 bar). The result is that there is high negative correlation between DGS and the germination percentage and the mean daily germination (MDG) (Table 2) and by increasing the concentration of SA and the level of droughtstress, daily germination speed increased. Comparison of the average priming interaction effect and drought stress. Comparing the means of priming interactions and drought stress are shown in (Figure 21). As can be seen, highest DGS is associated with $\mathrm{a} 4 \mathrm{~b} 4$ and treatment and the lowest DGS is associated with a3b1 treatment that is the inverse of MDG.

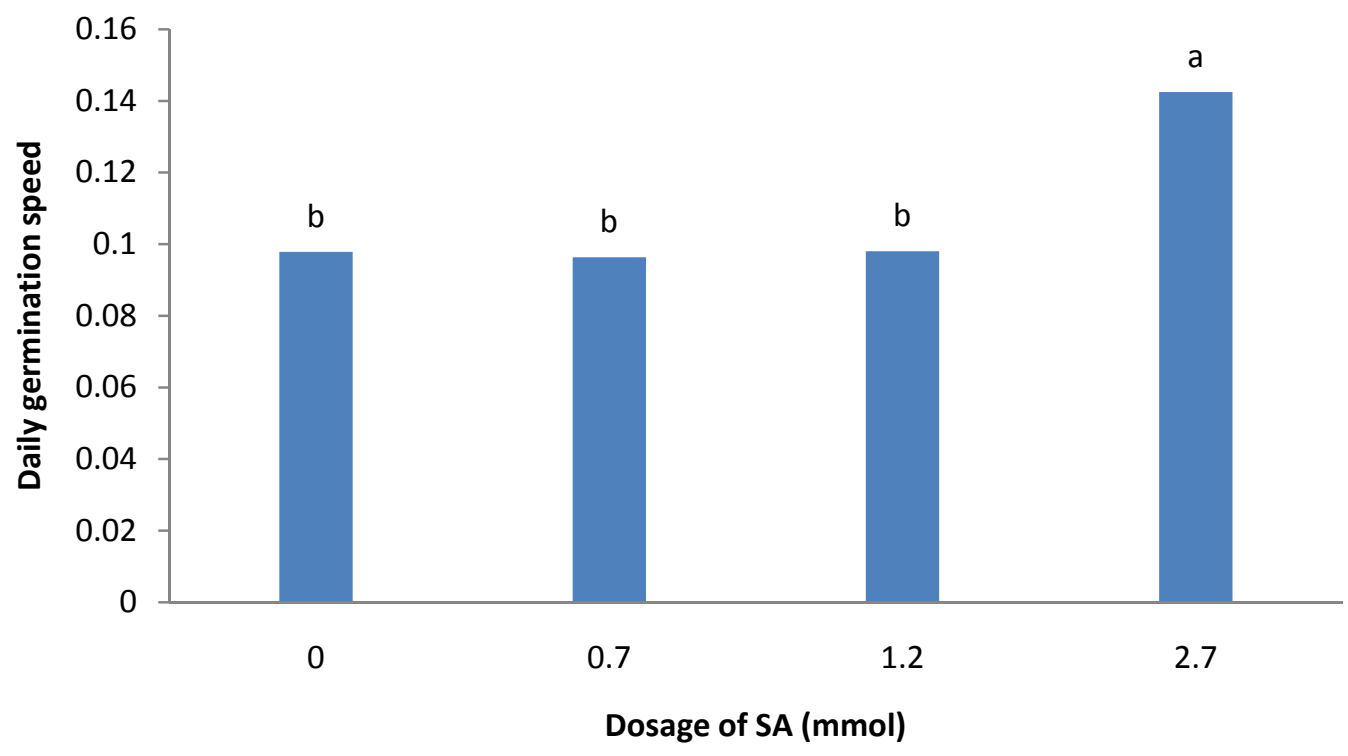

Figure 19. Effect of SA dosage on daily germination speed 


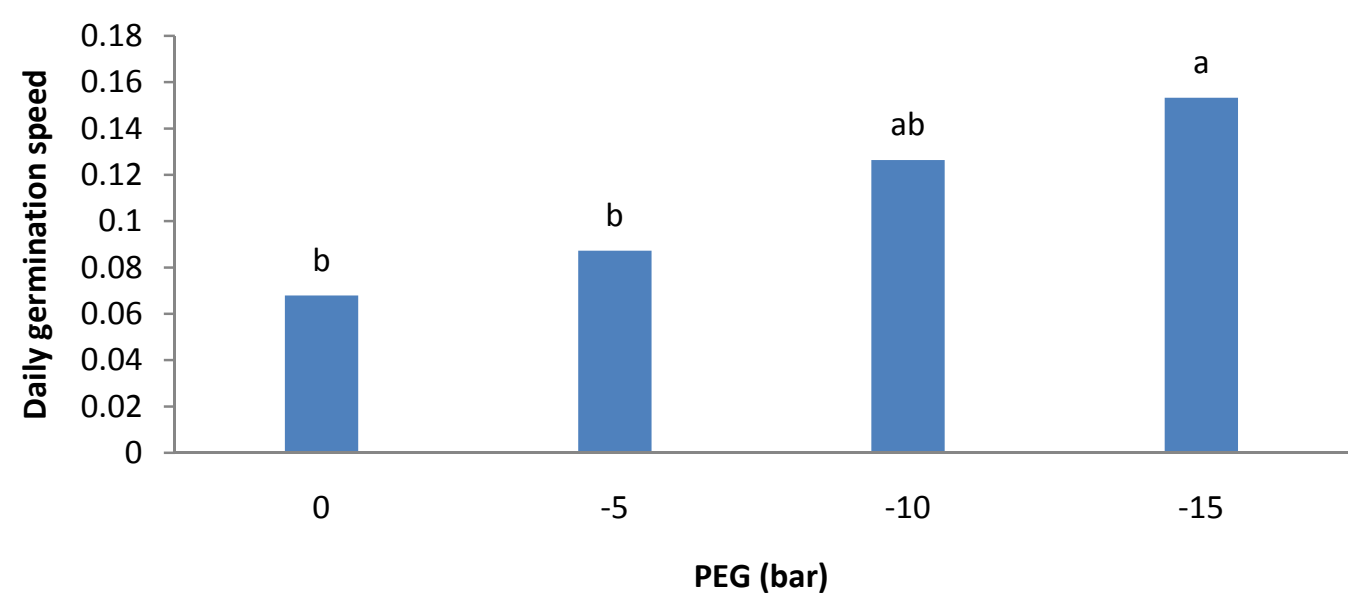

Figure 20. Effect of drought stress (PEG) on daily germination speed

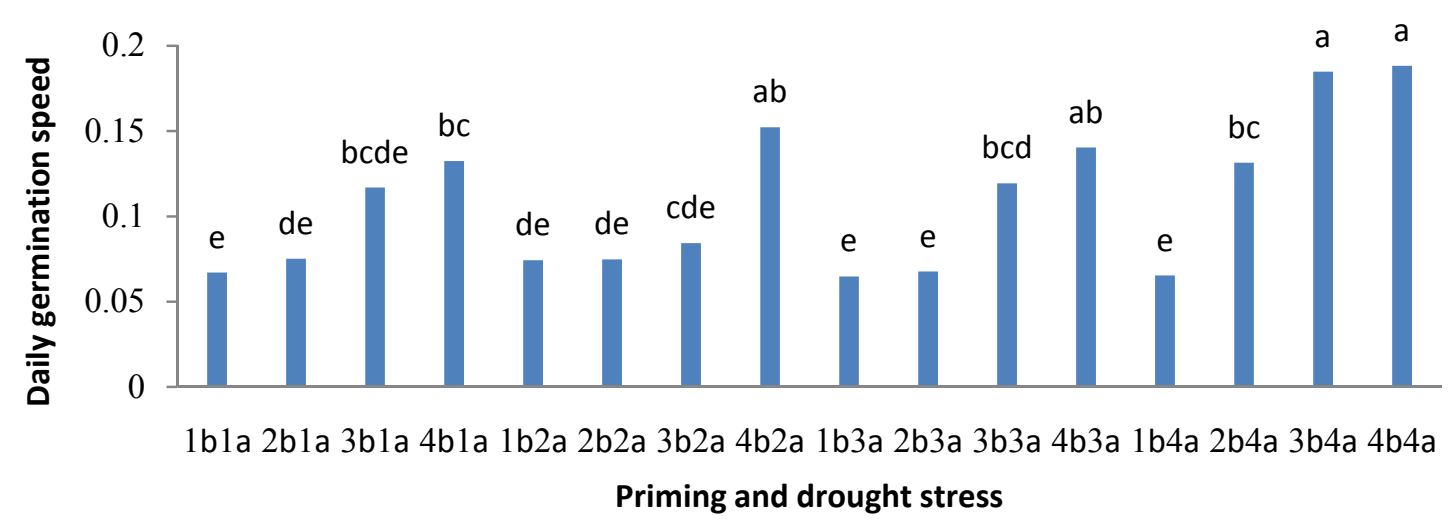

Figure 21. Effect of drought stress (PEG) and priming(SA)on daily germination speed

\subsection{Coefficient of Velocity of Germination ( CVG)}

Mean squares related to (CVG) are shown in Table1. This trait is one of the indicators related to the velocity and acceleration of daily germination. The results show that there is significant differences between main effects of priming and the level of drought stress, and there is also significant differences between interactions of these two factors at the level of $0.01 \%$. By comparing seed priming with different levels of SA in Duncan's test, we can be see that the highest germination speed was also associated with low doses of SA (Figure 22). Increased level of SA causes reducing CVG. There is high positive correlation $\left(0.971^{* *}\right)$ between this trait and the percentage of germination (Table 2). Bycomparing means of different level of drought stress with PEG, as it can be seen in (Figure 23), the highest CVG is associated with control treatment (without stress) and a little lower CVG is associated with low level of stress ( -5 bar). CVG is decreased by increasing stress. This trend also exists in comparing mean of interaction (Figure 24). As we can see the highest CVG is associated with alb1 treatment and a1b2 treatment and the lowest treatment is associated with a4b4 treatment. In one research, germination speed of Primed seeds (Fox mulberry plant) with salicylic acid under drought and salinity stress was more than the control treatment, but it was decreased with increasing salinity and drought stress, which is consistent with the results of this study (Zareand, 2000). 


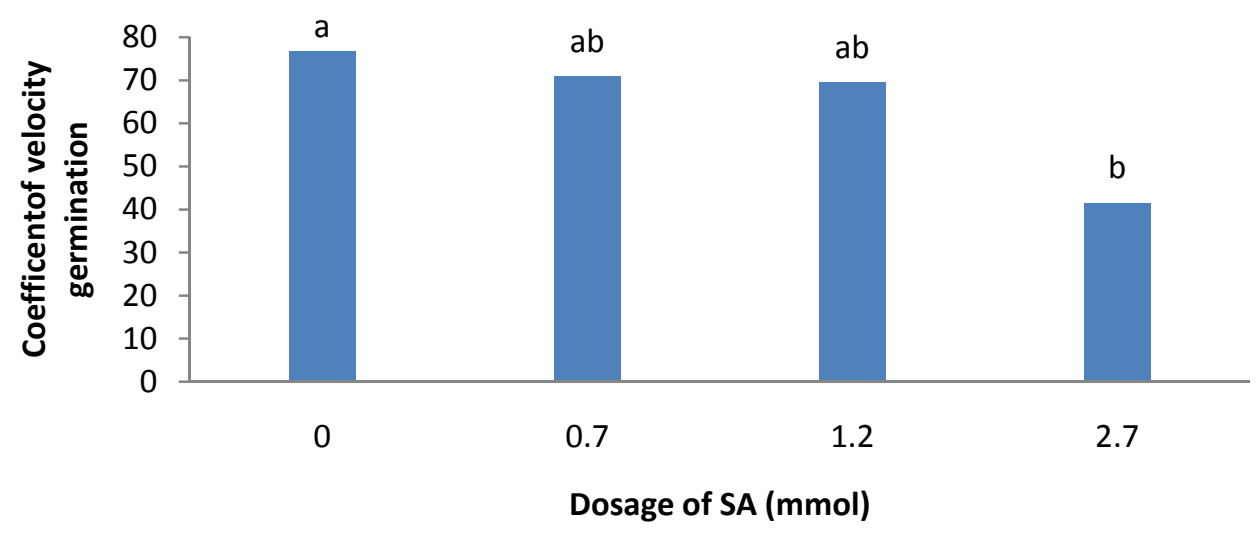

Figure 22. Effect of SA dosage on coefficient of velocity germination

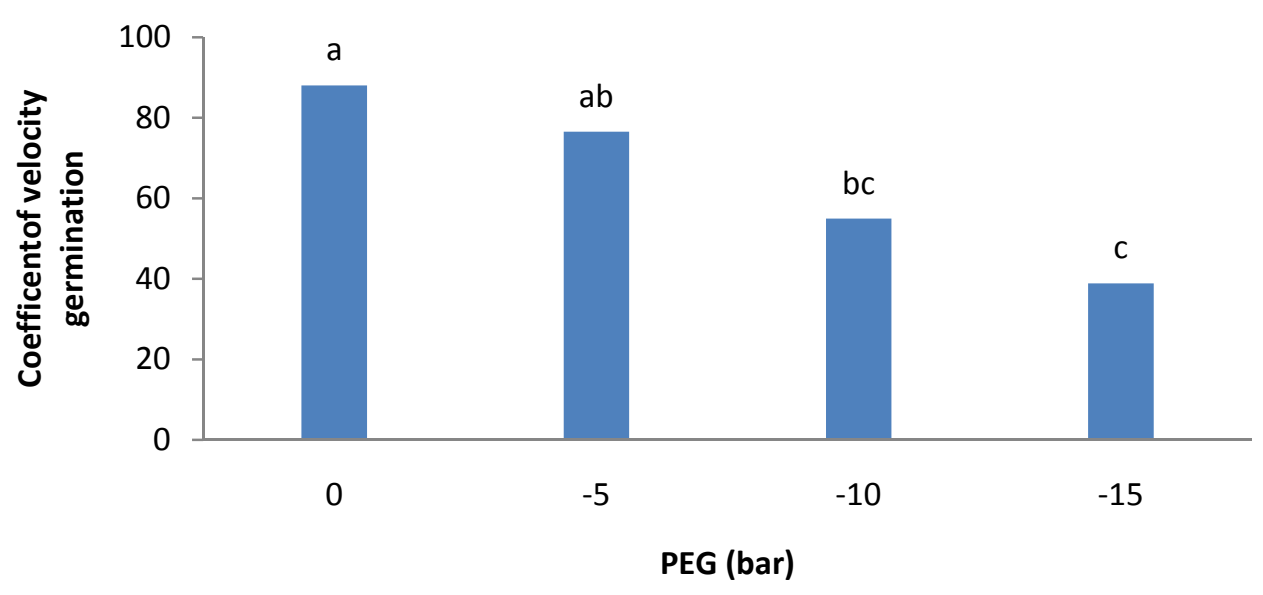

Figure 23. Effect of drought stress (PEG) on coefficient of velocity germination

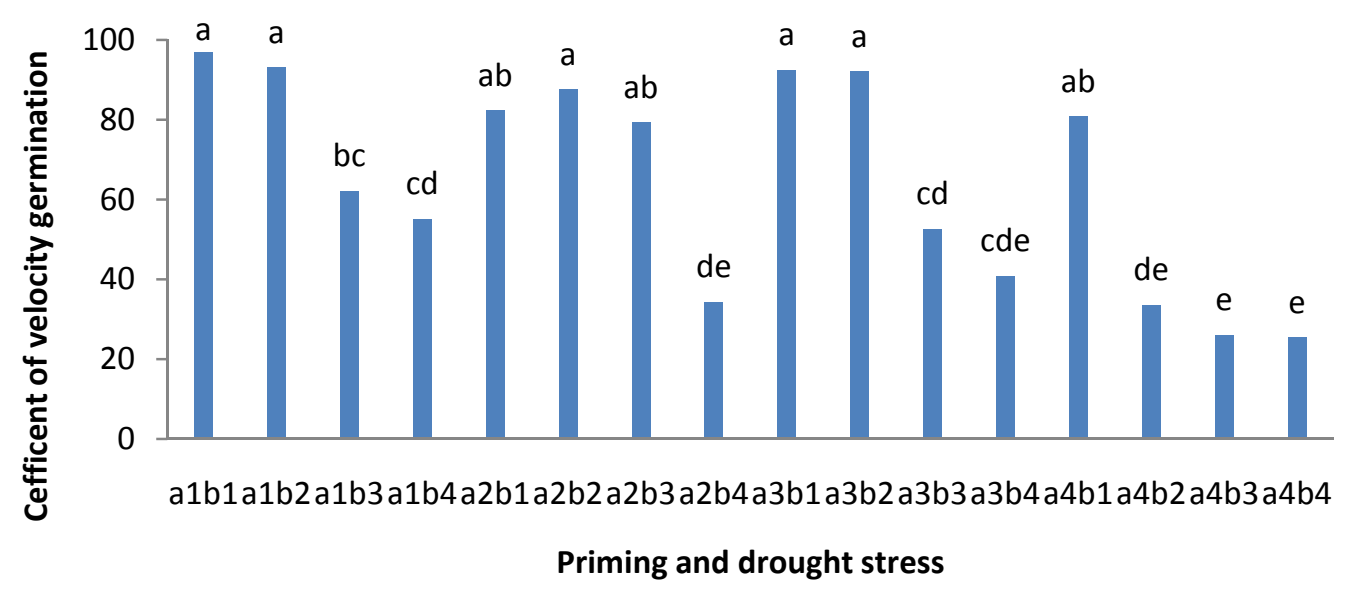

Figure 24. Effect of drought stress (PEG) and priming (SA) on coefficient of velocity germination 


\subsection{Energy of Germination ( $E G$ )}

The results of the table of the analysis of variance (Table 1) show that there is significant differences between main effects of prime and drought stress and also the interaction of these 2 traits at the level of $0.01 \%$. Comparison shows that the highest energy for germination is associated with high dose of SA hormones (Figure 25). And analysis of means of different levels of drought stress shown in Figure 26 indicatesthat maximum energy for germination is associated with high drought stress ( -15 bar). The result is that according to high negative and significant differences $\left(0.868^{* *}\right)$ between this trait and the percentage of germination (Table 2$)$, by increasing the level of stress and also increasing the dose of SA, more germination resistance increased, so required energy for germination will be increased. Comparing mean of effects between these 2 factors confirm that maximum germination energy is for treatments $\mathrm{a} 4 \mathrm{~b} 4, \mathrm{a} 4 \mathrm{~b} 3, \mathrm{a} 4 \mathrm{~b} 2$ and minimum is for treatment $\mathrm{a} 1 \mathrm{~b} 2$ (Figure 27).

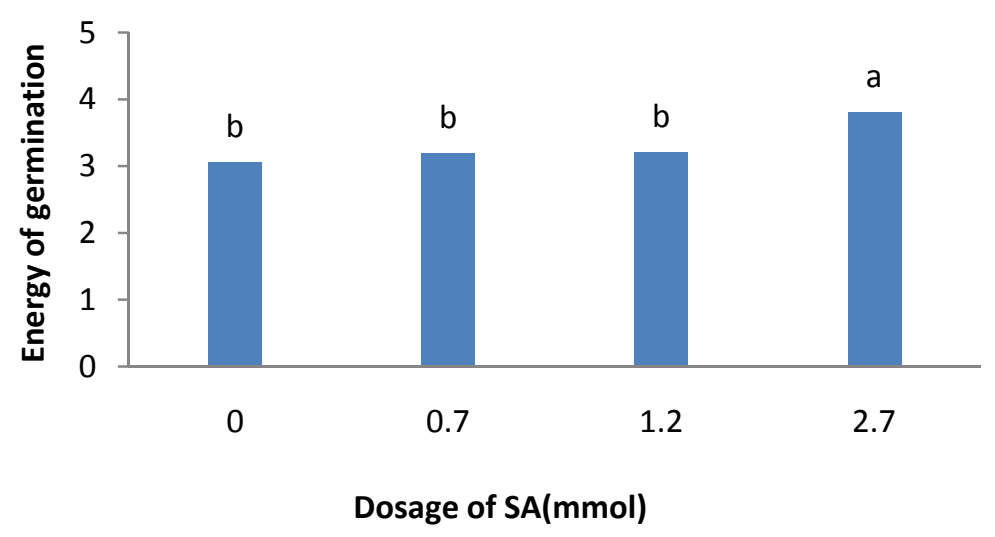

Figure 25. Effect of SA dosage on energy of germination

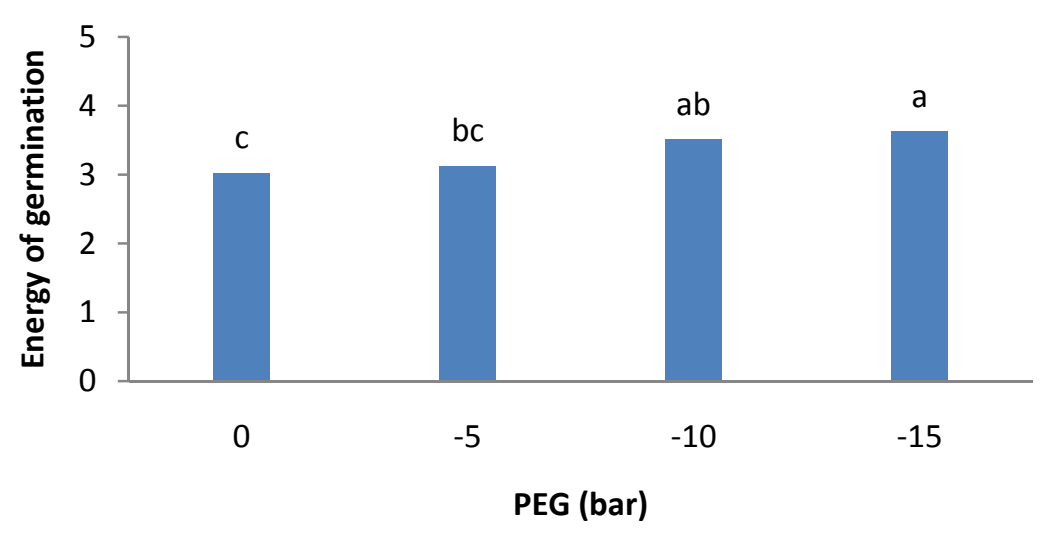

Figure 26. Effect of drought stress (PEG) on energy of germination 


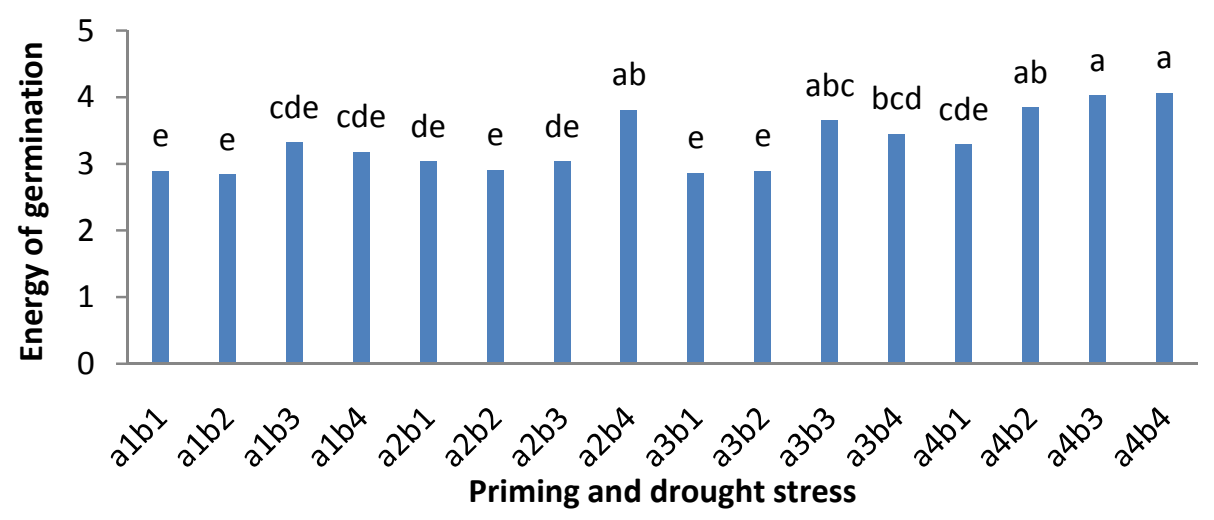

Figure 27. Effect of drought stress (PEG) and priming (SA) on energy of germination

\subsection{Allometric}

This trait is the ratio of radicle length to the length of the plumule and it is an indicator of germination vigor. As in can be seen in the analysis of variance (Table 1). Only the main effect of different levels of drought stress was significant at the level of $0.01 \%$. The priming factor and their interaction was not significant. Despite not being significant of different levels of priming with SA, Duncan test shows that the highest allometric is associated with $1.2 \mathrm{mM}$ and the lowest one is associated with $0.7 \mathrm{mM}$ (Figure 28). In other words, longer stem length, lower allometric and vice versa. There is significant negative correlation between these two traits $(-0.628 * *)$ (Table 2$)$.

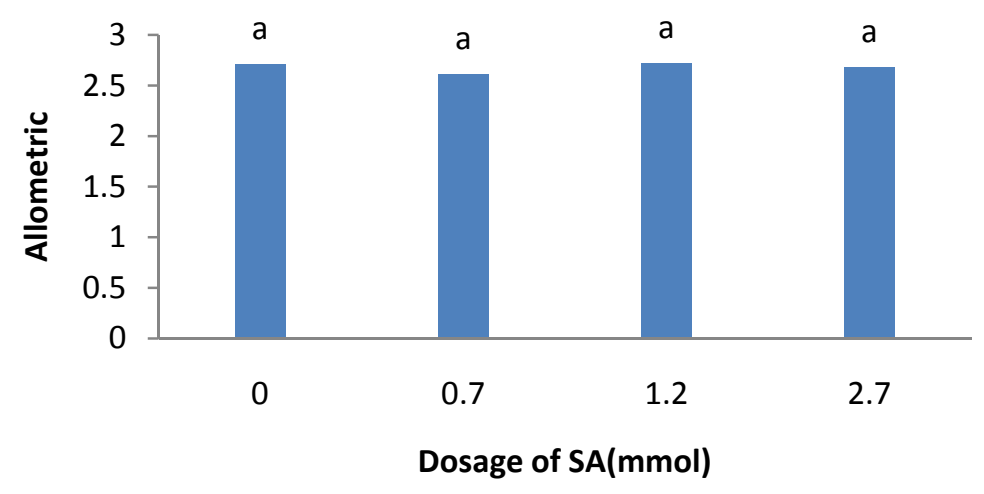

Figure 28. Effect of SA dosage on allometric

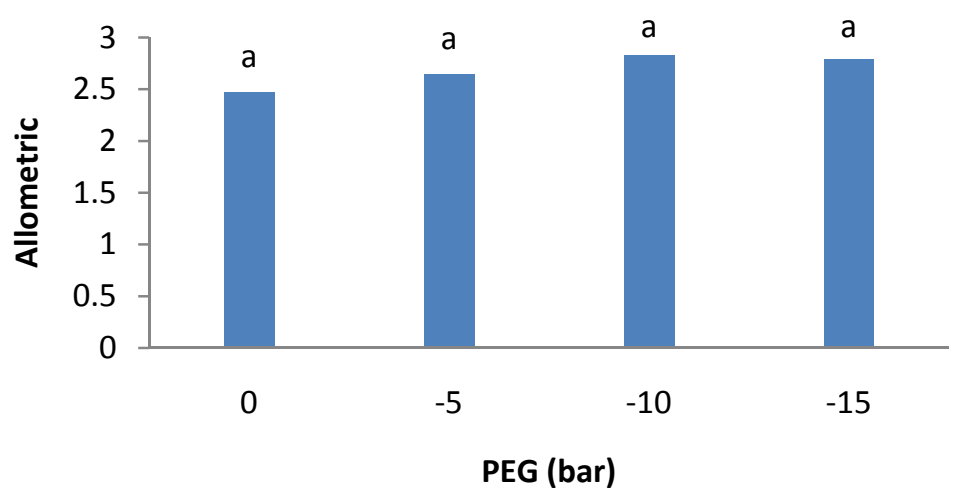

Figure 29. Effect of drought stress (PEG) on allometric 


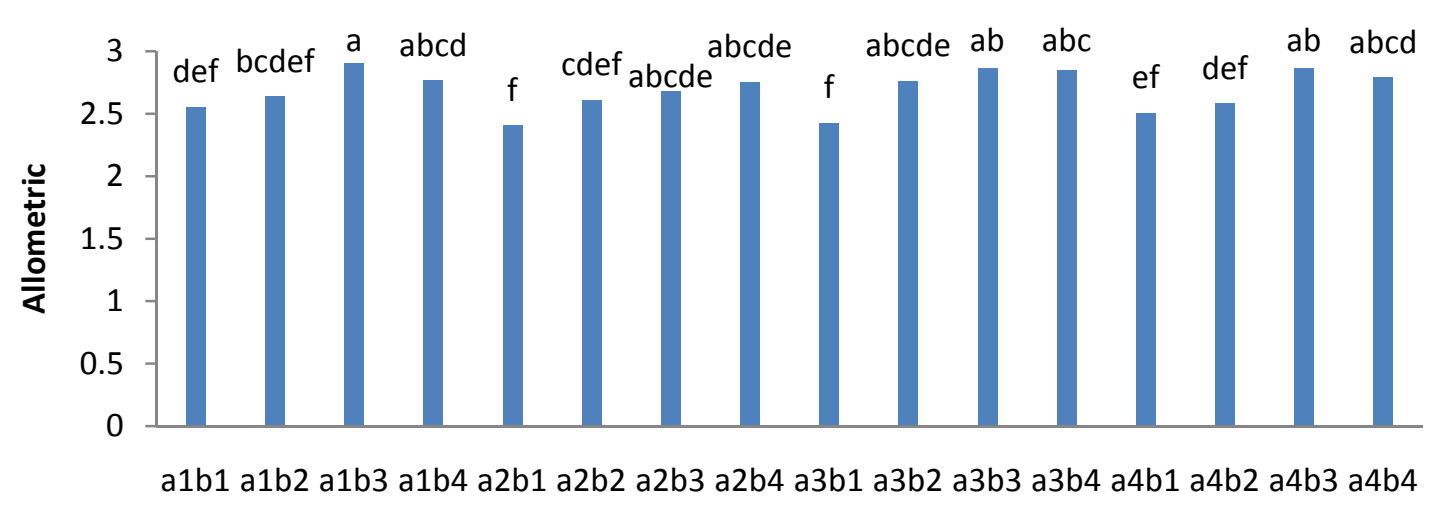

Priming and drought stress

Figure 30. Effect of drought stress(PEG) and priming(SA)on allometric

\subsection{Seedling Strength Index}

In this experiment, seedling strength index is calculated based on the radicle length. according to the table of analysis of variance (Table 1). As in can be seen in the analysis of variance (Table 1). Only the main effect of differentlevel of drought stress was significant at the level of $0.01 \%$. The priming factor and their interaction was not significant. The main factors and the factor of interaction between 2 treatments of drought stress and priming with SA were significant at the level of $0.01 \%$. It shows significant difference between at the level of each treatment. By comparing means of different levels of priming, it can be seen that Seedling strength index is decreased (Figure 31). This trend is also observed by comparison between different levels of drought stress (Figure 32) so that maximum Seedling strength index was seen in osmotic potential(-5 bar)and then in control treatment(withoutstress). By increasing PEG osmotic potential, seedling strength index is decreased. This trend is observed in comparison of means of interaction between priming and stress (Figure 33) so that maximum Seedling strength index was observed at low level of priming and drought stress (a2b2) and minimum Seedling strength index was observed in high dose of SA and high osmotic potential (a4b4). It shows there is high significant correlation $\left(0.765^{* *}\right)$ between this trait and the percentage of germination and mean daily germination $\left(0.765^{* *}\right)$ (Table 2).

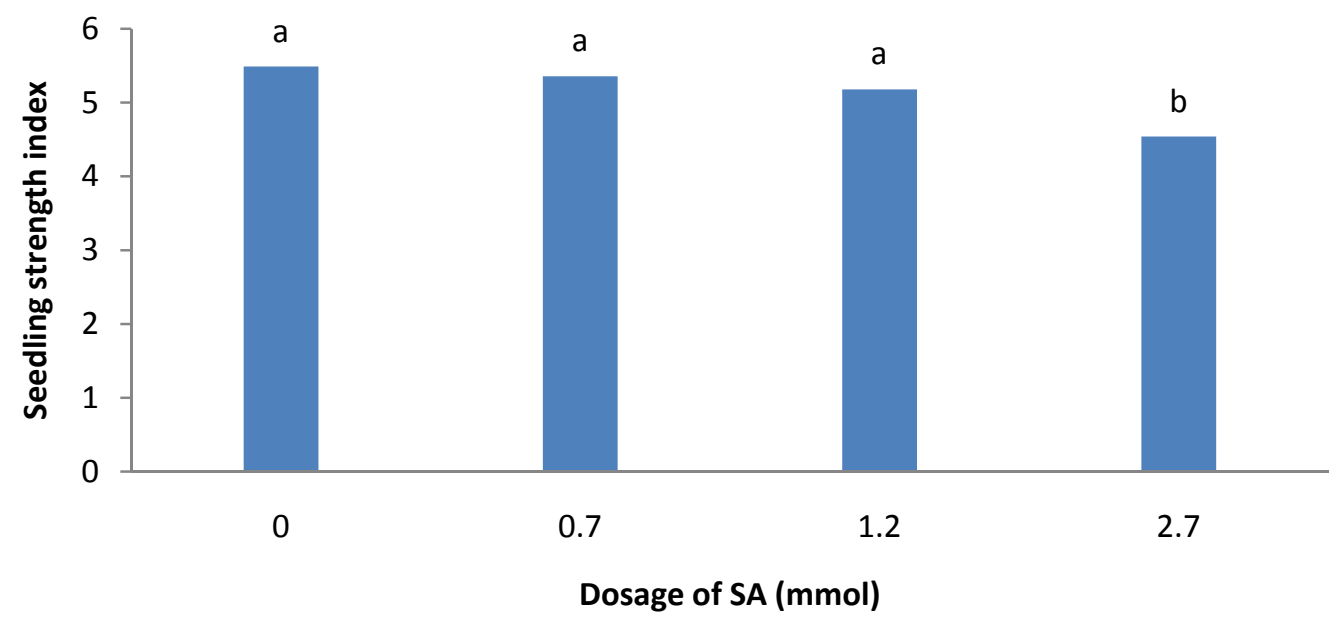

Figure 31. Effect of SA dosage on seedling strength index 


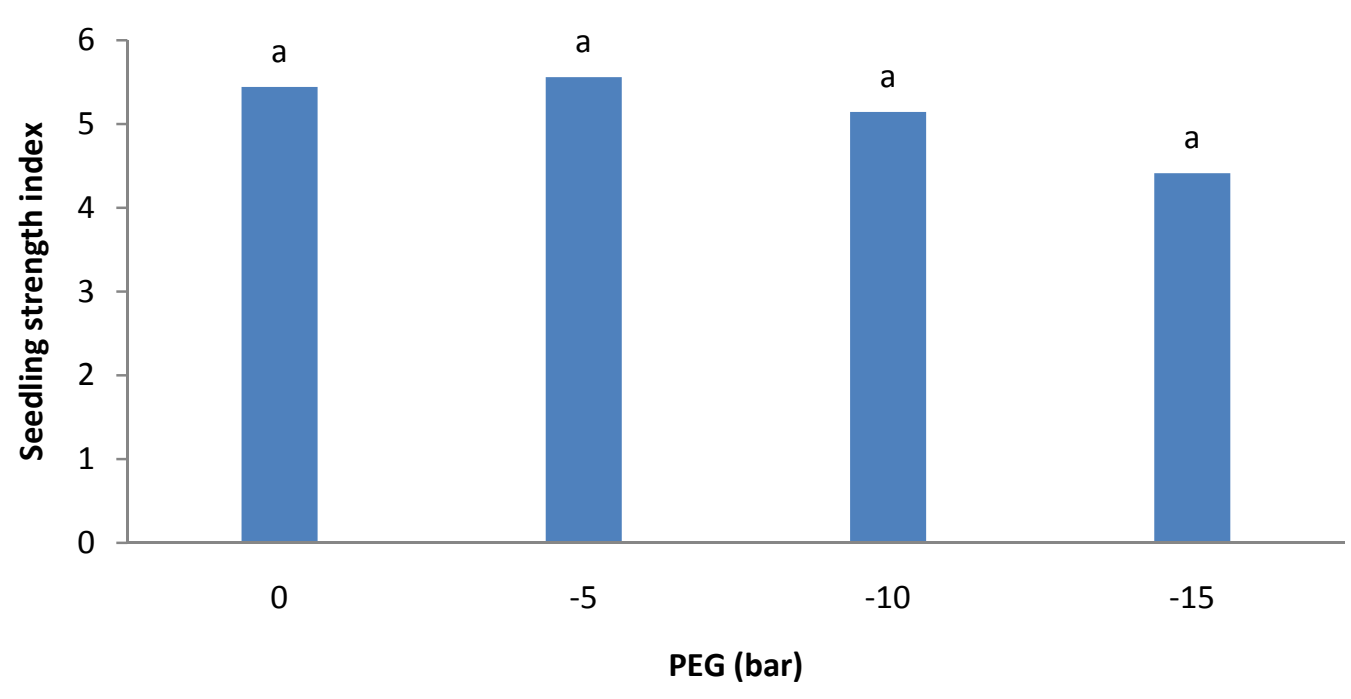

Figure 32. Effect of drought stress(PEG) on seedling strength index

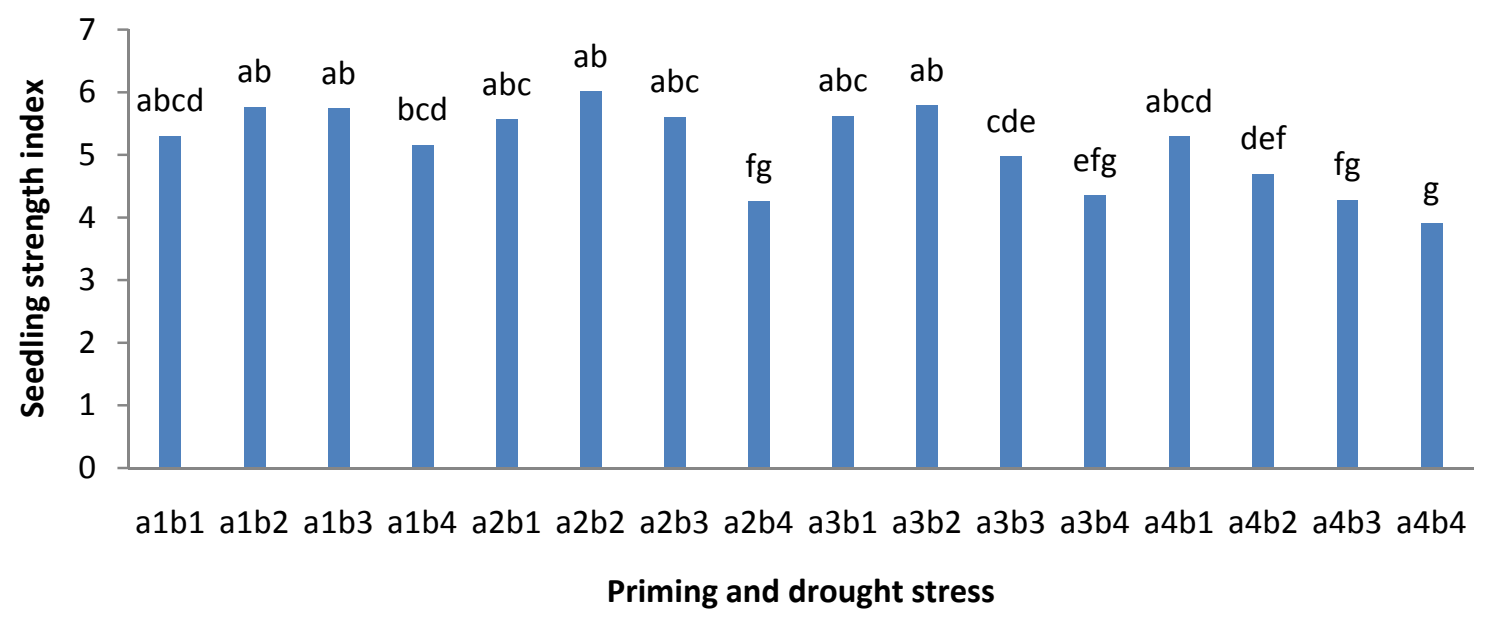

Figure 33. Effect of drought stress (PEG) and priming (SA)on seedling strength index

\subsection{Seed VIGOR}

Seed vigor index is also called power of seed or seed viability, it is the power and ability of seed emergence in difficult conditions (stress). As in can be seen in the analysis of variance (Table 1) all 3 factors (priming main factor, stress and the interactions between them have significant differences in this trait at the level of $0.01 \%$. comparison of means between different levels of seed priming with SA. By Duncan test shows that all levels are located in one group (Figure 34), however, low level of SA and control treatment (without stress) have maximum seed vigor and minimum seed vigor is associated with $2.4 \mathrm{mM}$ treatment. By comparing the means of different levels of drought stress due to PEG we can see that (Figure 35) maximum seed vigor is related to low level of drought stress and control treatment. By increasing osmotic potential due to PEG, seed vigor is decreased. Comparison of interaction between drought stress and seed priming with SA (Figure 36) shows that the highest seed vigor is associated with $\mathrm{a} 3 \mathrm{~b} 1, \mathrm{a} 2 \mathrm{~b} 1$ treatment. As expected, minimum seed vigor is related to $\mathrm{a} 4 \mathrm{~b} 4$. The result is that according to high positive correlation between this trait and percentage of germination $\left(0.870^{* *}\right)$ and mean daily germination $(0.864 * *)$ and coefficient of velocity of germination $(0.832 * *)$ and seedling strength index (0.731) (Table 2), when this trait is beside the low level of SA (a3, a2) and low level of drought stress or without stress, it will have maximum seed vigor. 


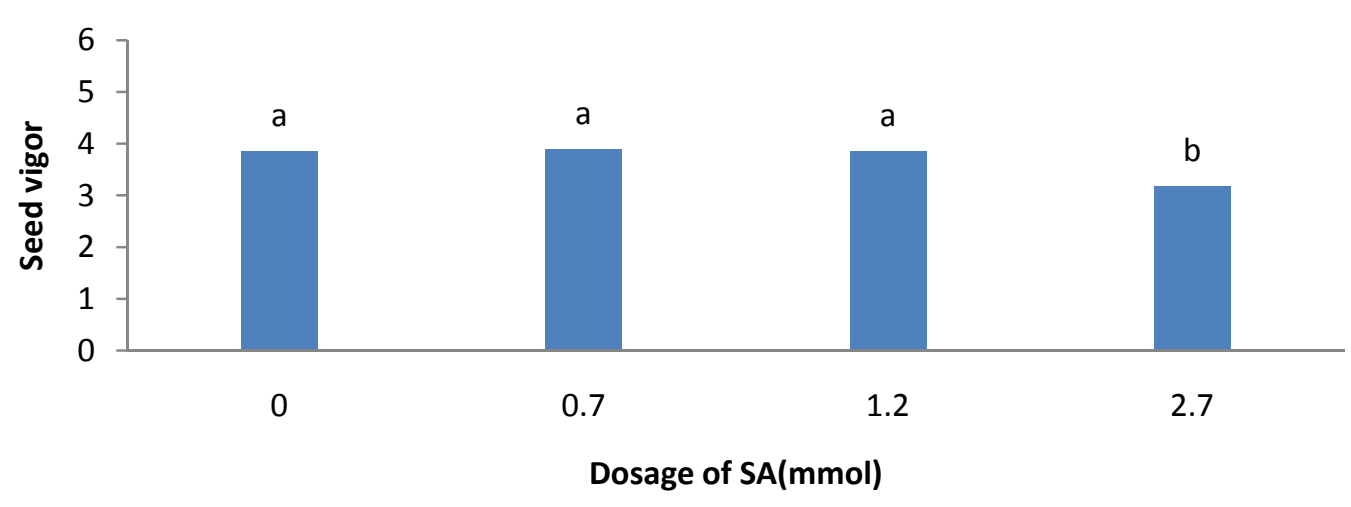

Figure 34. Effect of SA dosage on seed vigor

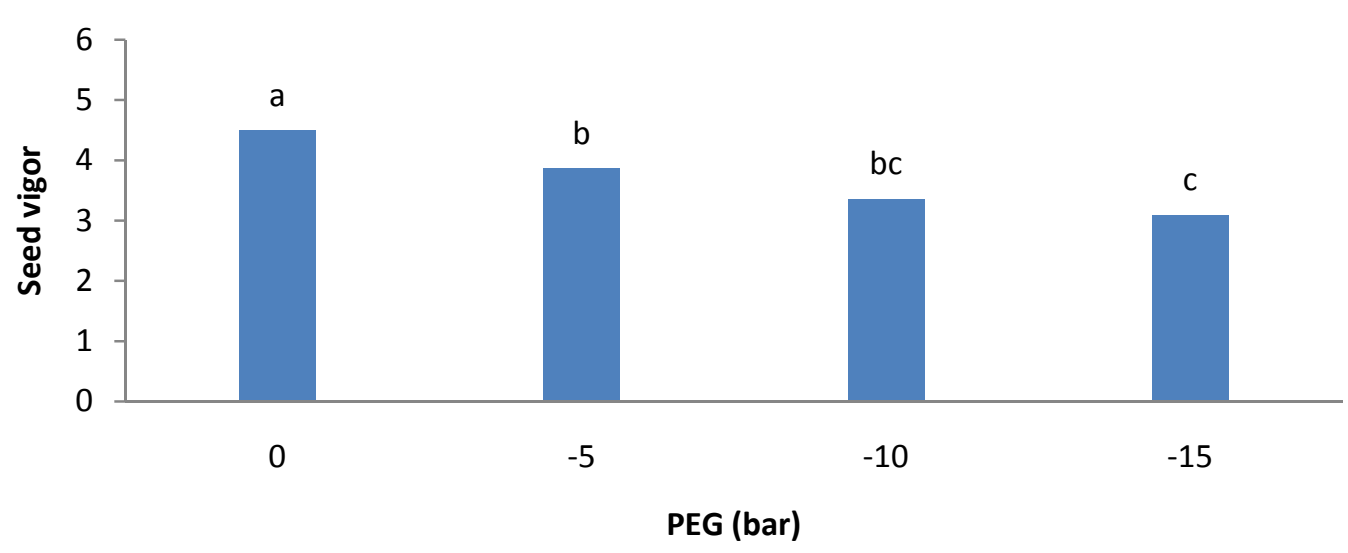

Figure 35. Effect of drought stress (PEG) on seed vigor

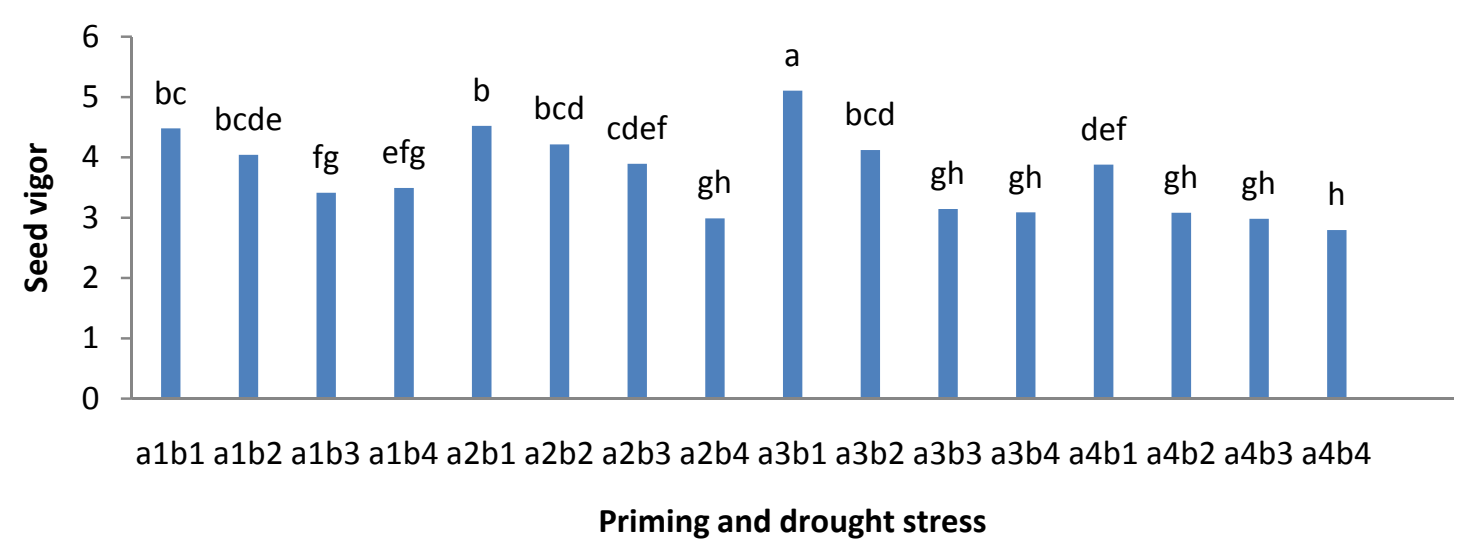

Figure 36. Effect of drought stress (PEG) and priming (SA) on seed vigor 
Table 2. Correlation coefficient among germination traits

\begin{tabular}{|c|c|c|c|c|c|c|c|c|c|c|c|c|}
\hline Parameters & Seed vigor & $\begin{array}{c}\text { Seedling } \\
\text { strength index }\end{array}$ & Allometric & $\begin{array}{c}\text { Energy of } \\
\text { Germination }\end{array}$ & $\begin{array}{c}\text { Length of } \\
\text { seedling }\end{array}$ & $\begin{array}{c}\text { Length of } \\
\text { plumule }\end{array}$ & $\begin{array}{l}\text { Length of } \\
\text { radicle }\end{array}$ & $\mathrm{CVG}$ & DGS & MDG & MTG & Germination $\%$ \\
\hline $\begin{array}{c}\text { Germinatio } \\
\mathrm{n} \%\end{array}$ &.$/ 870^{* * *}$ &.$/ 765 * *$ & $-/ 501 * *$ &.$- / 868^{* * *}$ &.$/ 712^{* *}$ & /.604** &.$/ 363^{* *}$ &.$/ 971^{* *}$ & $-/ 935^{* *}$ &.$/ 988^{* *}$ &.$/ 005 \mathrm{~ns}$ & 1 \\
\hline MTG &.$- / 0407 \mathrm{~ns}$ & $.009 \mathrm{~ns}$ & $-/ 109$ ns &.$/ 134 \mathrm{~ns}$ & $-/ 0109 \mathrm{~ns}$ &.$/ 104 \mathrm{~ns}$ & $-/ 055 \mathrm{~ns}$ & $-/ 048 \mathrm{~ns}$ &.$- / 070 \mathrm{~ns}$ &.$/ 018 \mathrm{~ns}$ & 1 & $.005 \mathrm{~ns}$ \\
\hline MDG & $.864 * *$ & $.7765^{* *}$ & $-/ 506^{* *}$ &.$- / 863^{* * *}$ & $.7725^{* *}$ & $/ 590^{* * *}$ &.$/ 395^{* *}$ &.$/ 963^{* *}$ &.$- / 944^{* * *}$ & 1 &.$/ 018 \mathrm{~ns}$ &.$/ 988^{* *}$ \\
\hline DGS & $-/ 808^{* *}$ &.$- / 783^{* *}$ &.$/ 492 * *$ &.$/ 854^{* *}$ & $-/ 650^{* * *}$ &.$- / 579 * *$ & $-/ 416^{* *}$ &.$- / 932^{* * *}$ & 1 &.$- / 944^{* *}$ &.$- / 070 \mathrm{~ns}$ &.$- / 935^{* *}$ \\
\hline CVG &.$/ 832 * *$ &.$/ 772 * *$ & $-/ 478^{* *}$ &.$- / 903 * *$ &.$/ 659 * *$ & $/ 562^{* * *}$ & $/ 361^{* *}$ & 1 &.$- / 932^{* * *}$ & $/ 963^{* *}$ & $-/ 048 \mathrm{~ns}$ & /971** \\
\hline $\begin{array}{l}\text { Length of } \\
\text { radicle }\end{array}$ &.$/ 371^{* * *}$ &.$/ 588 * *$ & $-.024 \mathrm{~ns}$ &.$- / 359 * *$ &.$/ 406^{* *}$ &.$/ 209 \mathrm{~ns}$ & 1 &.$/ 361^{* *}$ & $-/ 416^{* *}$ &.$/ 395^{* *}$ & $-.055 \mathrm{~ns}$ &.$/ 363^{* *}$ \\
\hline $\begin{array}{l}\text { Length of } \\
\text { plumule }\end{array}$ & $.744 * *$ &.$/ 539 * *$ & $.628^{* * *}$ &.$- / 534^{* *}$ &.$/ 722^{* *}$ & 1 &.$/ 209 \mathrm{~ns}$ & $/ / 562 * *$ & $-/ 579^{* *}$ &.$/ 590^{* *}$ &.$/ 104 \mathrm{~ns}$ &.$/ 604^{* *}$ \\
\hline $\begin{array}{l}\text { Length of } \\
\text { seedling }\end{array}$ & $.857^{* * *}$ &.$/ 561 * *$ & $-/ 554^{* *}$ &.$- / 627^{* *}$ & 1 &.$/ 722^{* *}$ &.$/ 406 * *$ &.$/ 659^{* * *}$ &.$- / 650^{* *}$ &.$/ 725^{* *}$ &.$/ 019 \mathrm{~ns}$ &.$/ 712^{* *}$ \\
\hline $\begin{array}{c}\text { Energy of } \\
\text { Germinatio } \\
n\end{array}$ &.$- / 810^{* *}$ &.$- / 786^{* * *}$ &.$/ 405^{* *}$ & 1 &.$- / 627^{* *}$ & $-/ 534^{* *}$ & $--/ 359^{* *}$ & $-/ 903^{* *}$ &.$/ 854^{* *}$ &.$- / 863^{* *}$ &.$/ 134 \mathrm{~ns}$ &.$- / 868 * *$ \\
\hline Allometric &.$- / 555^{* *}$ & $-.250^{*}$ & 1 &.$/ 405^{* *}$ & $-/ 544^{* *}$ & $-/ 628^{* *}$ &.$- / 024 \mathrm{~ns}$ & $-/ 478^{* *}$ &.$/ 492 * *$ &.$- / 506^{* *}$ & $-/ 109 n s$ &.$- / 501^{* *}$ \\
\hline $\begin{array}{l}\text { Seedling } \\
\text { strength } \\
\text { index }\end{array}$ & $.7731^{* *}$ & 1 & $-/ 250^{*}$ &.$- / 786^{* * *}$ &.$/ 561^{* *}$ & $/ 539 * *$ &.$/ 588^{* *}$ & $.7722^{* *}$ &.$- / 783^{* *}$ & $.765^{* *}$ & $.009 \mathrm{~ns}$ & $.7765^{* *}$ \\
\hline Seed vigor & 1 & $.7731 * *$ & $-/ 555 * *$ &.$- / 810^{* * *}$ &.$/ 857^{* *}$ & . $/ 744^{* * *}$ &.$/ 371^{* *}$ &.$/ 832^{* *}$ &.$- / 808^{* * *}$ &.$/ 864 * *$ & $-/ 047 \mathrm{~ns}$ &.$/ 870^{* * *}$ \\
\hline
\end{tabular}

ns: non significant, ${ }^{*},{ }^{* *}$ : respectively significant $(\mathrm{p} \leq 0.05)$ and highly significant $(\mathrm{p} \leq 0.01)$.

\section{Conclusion}

Salicylic acid improves germination by neutralizing free radicles or active oxygen.Seed priming increases enzyme of antioxidants such as glutathione and ascorbate in seed. These enzymes decrease the activities of lipid peroxidation in stage of germination. As a result, increasese the percentage of germination. The greatest effect of SA on decreasing the germination time is at the low level of stress and maximum percentage of germination and effective traits on it, was obtained by seed soaking in SA $(0.7 \mathrm{mM})$. The best result was obtained in low level of drought stress. The percentage of germination had positive significant correlation with mean daily germination $\left(0.988^{* *}\right)$, CVG or coefficient of velocity of germination $\left(0.971^{* *}\right)$, radicle length $\left(0.363^{* *}\right)$, plumule length $(0.604)$, seedling length $\left(00.712^{* *}\right)$, seedling strength index $\left(000.765^{* *}\right)$, seed vigor $\left(0.870^{* *}\right)$ and negative significant correlation with daily germination speed $\left(-0.935^{* *}\right)$, germination energy $\left(-0.868^{* *}\right)$ and allometric trait ( -0.501). In high concentration of SA and high level of drought stress, more energy is required for germination and germination time is decreased. Seed vigor and seedling strength index was decreased in high level of stress and the high concentration of SA.

\section{Acknowledgment}

I am very thankful from my college in Seed certification department of Safiabad Research Center specially Mr. Hassan nourinejad, Saeid Khajezadeh, Ahmad Mohammadalipour, Mis Mehri Khetshzar.

\section{References}

Al- Hakimi, A. M. A. (2006). Counteraction of drought stress on soybean plants by seed soaking in salicylic Acid. International J.of Botany, 2(4), 421-426.

Abdul-Baki, A. A., \& Anderson, J. D. (1973). Vig our. Determination in soy bean by multiplecriteria. Cropscienc, 13, 630-633.

Agarwal, S., Sairam, K. R., Srivastava, G. C., Aruna, T., \& Meena, C. R. (2005). Role of ABA, Salicylic acid, calcium and hydrogen peroxide on antioxidant enzymes induction in wheat seed lings. Plant Sci., 169, 559-570. http://dx.doi.org/10.1016/j.plantsci.2005.05.004

Agrawal, R. (2003). Seed Technology. Newdehli India: Pub.co. Ltd.

Bezrukova, M., Sakhabutdinova, V., Fatkhutdinova, R., Kyldiarova, R. A., Shakirova, I., \& Sakhabutdinova, F. A. R. (2001). The role of hormonal changes in protective action of salicylic acid on growth of wheat seedling under water deficit. Agrochemiya (Russ), 2, 51-54.

Cakmad, I., \& Horst, W. (1991). Effect of aluminium on lipid peroxidation, superoxide dismutase, catalase and peroxidase activities in root tip of soybean (Glysin max). Plant Phisiol., 83, 463-468. http://dx.doi.org/10.1111/j.1399-3054.1991.tb00121.x 
Ellis, R. H., \& Roberts, E. H. (1981). The quantification of ageing and survival in orthodox seeds. Seed Sci. and Technology, 9, 377-409.

Gomez, L., Blanca, L., \& Antonio, C. S. (1993). Evidence of the be seedlings induced by salicylic acid and salinity. Plant Sci., 164, 317-322.

Hamada, A. M., \& Al- Hakimi, A. M. A. (2001). Salicylic acid versus salinity drought induced stress on wheat seedlings. Rostlinna Vyroba, 47.

Hanan, E. D. (2007). Influence of salicylic Acid on stress tolerance during Seed germination of Triticum aestivum and Hordeum vulgare. Advances in Biological Res, 1(1-2), 40-48.

Huntr, E. A., Glasbey C. A., \& Naylov, R. E. L. (1984). The analysis of data from germination tests. Journal of Agricultural Science, 102, 207-213. http://dx.doi.org/10.1017/S0021859600041642

Hus, J. L., \& Sung, J. M. (1997). Antioxidant role of glutatnione associated with accelerated agina and hydration of triploid Watermelon seeds. Physioga Plantarum, 100, 967-974.

Maguire, J. D. (1962). Seed of germination - aid in selection and evaluation for seedling emergence and vigor. Crop Sci., 2, 176-177.

Nico ls, M. A., \& Heydecker, W. (1968). Two approaches to thestudy ofgermination date, Proc. In to seed test. Asso., 33, 561-540.

Scott, S. J., Jones, R. A., \& Willams, W. A. (1984). Review of data analysis methods for seed germination. Crop Sci., 24, 1192-1199.

Shakirova, F. M., \& Bezrukova, M. V. (1997). Induction of wheat resistance against environmental salinization by salicylic acid. Biology Bulletin, 24, 109-112.

Zare, S., \& Tavili, A. (2000). Study effect diffrents level salicylic acid on emprovment germination traits fox mulberry plant under drought and salinity range and natural sources. Iran Bulletin, 1, 29-39

Zhou, Z. S., Guo, K., Abdou, E., Yang, A., \& Zhang, M. (2009). Salicylic acid alleviates mercury toxicity by preventing oxidative stress in roots of Medicago sativa. Environmental and Experimental Botany, 65, 27-34. 